\title{
Article \\ Underfloor Heating Using Room Air Conditioners with Air Source Heat Pump in a Foundation Insulation House
}

\author{
Hiroki Ikeda ${ }^{1}$, Yasushi Ooi ${ }^{2}$ and Takashi Nakaya ${ }^{3, * \text { (D) }}$ \\ 1 DAI-DAN Co., Ltd., Miyoshi-machi, Iruma-gun, Saitama 354-0044, Japan; ikedahiroki@daidan.co.jp \\ 2 OOIKENSETSUKOUGYOU Co., Ltd., Kitasaku-gun, Nagano 389-0207, Japan; ooi@ooi-kensetsu.co.jp \\ 3 Department of Architecture, Faculty of Engineering, Shinshu University, Nagano 380-0928, Japan \\ * Correspondence: t-nakaya@shinshu-u.ac.jp
}

check for updates

Citation: Ikeda, H.; Ooi, Y.; Nakaya, T. Underfloor Heating Using Room Air Conditioners with Air Source Heat Pump in a Foundation Insulation House. Energies 2021, 14, 7034. https://doi.org/10.3390/ en14217034

Academic Editor: Xi Chen

Received: 10 August 2021

Accepted: 21 October 2021

Published: 27 October 2021

Publisher's Note: MDPI stays neutral with regard to jurisdictional claims in published maps and institutional affiliations.

Copyright: (C) 2021 by the authors. Licensee MDPI, Basel, Switzerland. This article is an open access article distributed under the terms and conditions of the Creative Commons Attribution (CC BY) license (https:/ / creativecommons.org/licenses/by/ $4.0 /)$.

\begin{abstract}
A good thermal environment is important in a place where occupants stay for a long time. Since heating a house consumes a lot of energy, an energy-efficient heating method will be required. Then, by combining a heat pump and underfloor heating, there is a possibility that both thermal comfort and energy saving can be achieved. The survey was conducted on a detached house located in Nagano Prefecture, Japan. The average outside air temperature was $4.2{ }^{\circ} \mathrm{C}$. This study investigated the indoor thermal environment, evaluated the operating performance of the heat pump, and calculated the heat load by two-dimensional analysis. More than $80 \%$ of the subjects were satisfied with the thermal environment and the neutral temperature was $18.9^{\circ} \mathrm{C}$. In the operation of the heat pump, defrost operation was confirmed, but the average COP was 2.9, and it operated efficiently. In addition, the heat loss from the foundation slab was examined. Proper insulation placement has shown the potential to reduce heat loss. In conclusion, the use of heat pumps as a heat source has been shown to be efficient even in cold climates, and this study supports the construction of new heating methods.
\end{abstract}

Keywords: cold region; house; heated crawl space; air source heat pump; foundation insulation; thermal comfort

\section{Introduction}

In an indoor environment, it is desirable to maintain the thermal comfort of occupants. Local thermal environments, such as vertical air temperature differences and floor surface temperatures, affect the thermal comfort of occupants [1,2]. Japanese housing design aims to achieve energy savings by insulating a foundation wall [3]. It is expected that the heated crawl space can be treated in the same way as indoors. Therefore, a heating method has been proposed in which the heated crawl space is used as an air movement path. The crawl space heating raises the floor surface temperature and can reduce the local thermal discomfort at the feet. Furthermore, a uniform indoor temperature distribution is expected. There is no need to arrange ducts, and room air conditioners equipped with an air heat source heat pump can be used as air conditioning equipment. Heating using a heat pump is energetically efficient. The combination of crawl space heating and air source heat pump has the potential to provide both thermal comfort and energy savings.

A room air conditioner equipped with an air heat source heat pump is highly efficient. Even in cold regions, heat pumps that use air heat sources are used. A Previous study investigated a heating method that combines floor heating and an air conditioner with an air source heat pump [4]. The introduction of a heat pump has shown the potential to reduce energy consumption while maintaining comfort. However, some studies have reported that frost on heat pump evaporators reduces their operating efficiency during the heating period [5-8]. Asama et al. [6] showed that the COP in the practical operation was lower than the rated COP during heating. In addition, the COP decreased as the indoor/outdoor temperature difference increased. Wang et al. [7] showed that when $60 \%$ 
of the surface of the evaporator frosted, the COP was reduced to 2.3. The COP decreased by $40.4 \%$, and the output heat capacity decreased by $43.4 \%$. Guo et al. [8] indicated the outside air temperature is approximately $0{ }^{\circ} \mathrm{C}$; the higher the outside air relative humidity $(65 \%, 75 \%$, and $85 \%)$, the larger the frost thickness. In this study, the possibility of frost formation is investigated based on the refrigerant temperature. In addition, to maintain thermal comfort, it is necessary to discuss the effect of switching between heating operation and defrost operation in the indoor environment.

The heating method using the crawl space may be able to operate the entire house efficiently. Crawl space heating has characteristics similar to underfloor air distribution (UFAD). UFAD is a system that uses the space created by a raised floor to deliver air from under the floor to the room [9]. The appropriate design of UFAD can improve thermal comfort [10-13], ventilation efficiency, and air quality [11,14] and reduce energy consumption [15-18]. Previous studies investigated parameters such as fan shape [19,20], installation location [20], and supply air flow rate [21,22]. Although improvements to the indoor environment were attempted, there is a risk of heat loss from the underfloor space. Schiavon et al. [23] showed that the cooling load for the raised floor construction was higher than that for the non-raised floor construction. Bauman et al. [24] indicated that part of the total indoor cooling load was caused by heat transfer from the room to the underfloor space. Schiavon et al. [25] pointed out the heat load caused by the heat gained from the floor panels and structures as cooling air passed under the floor. Lee et al. [26] studied the effect of thermal decay on energy consumption through an analysis. Due to thermal decay, the temperature of the supplied air increased by an average of $3.7 \mathrm{~K}$ per year compared to ducted air conditioning. Similar to these results, in the crawl space of a detached house, heat loss occurs from the foundation slab toward the ground. Liu et al. [27] indicated that heat was lost from the underfloor space to the ground when the underfloor space is used as the movement path for heating air. Rantala [28] showed that an increase in the average slab temperature by $6{ }^{\circ} \mathrm{C}$ increased the average annual heat loss from the building to the ground by approximately $45 \%$. On the other hand, it has been shown that the heat load in the underfloor space can be reduced by proper insulation placement. Yu et al. [29] introduced an adiabatic structure into the UFAD system and compared and analyzed the energy consumption with ceiling-type air conditioning. The non-insulated UFAD system was affected by thermal decay, and the air-conditioning load increased by $31.7 \%$ compared to ceiling air conditioning. The adiabatic UFAD system has a $6.2 \%$ reduction in the air conditioning load compared to ceiling air conditioning. Regarding the foundation slab, Krarti placed horizontal insulation [30,31] or vertical insulation [32,33] to the foundation slab and analyzed it under steady and unsteady conditions. He analyzed the relationship between the insulation dimensions and heat loss from the foundation slabs. Hagentoft [34] investigated the effect of reducing heat loss caused by the length of the insulation and the angle of installation of the insulation for the ground surface. Iwamae et al. [35] performed a numerical analysis to determine the relationship between parameters such as the dimensions of the heat-insulating material, soil thermal conductivity, and the amount of heat loss. Previous studies have reported on the relationship between insulation dimensions and heat loss; however, in heated crawl space, heat loss is promoted due to high air temperature and air velocity. Therefore, in this study, in addition to the type of insulation arrangement, the air temperature, and air velocity conditions were divided into foundation areas for two-dimensional analysis. In addition, based on the analysis results, the insulation arrangement was examined from the viewpoint of cost effectiveness.

By conducting a field survey of the thermal environment, we will examine the practicality of a method that combines an air source heat pump and crawl space heating. In Japan, the mainstream method is to heat only the living room with a wall-mounted air conditioner. Therefore, there is a risk that a horizontal temperature distribution will occur in the living room or the entire house. Previous studies have shown that the combination of underfloor heating and mechanical ventilation can efficiently heat a living area $1.7 \mathrm{~m}$ above the floor and provide a uniform horizontal temperature distribution [36]. Based 
on this knowledge, it is expected that the same effect can be obtained in the crawl space heating houses, and there is room for the examination of thermal comfort. In Japan, some research has been conducted on air conditioning systems that use the crawl space, but there are few research results [37-39]. This study conducts a thermal environment survey and a subjective survey.

If the air source heat pump operates efficiently, the indoor thermal environment is satisfactory for the occupants, and the insulation placement for a foundation slab that suppresses heat loss is shown, the crawl space heating with an air source heat pump may be proposed as a new heating method for a detached house.

\section{Methods}

This research examined the indoor thermal environment by field survey, the COP measurement of the air source heat pump, and relationship between insulation placement and heat loss.

\subsection{Target Detached House}

The target of the study was a detached house located in Saku City, Nagano Prefecture $\left(36.25^{\circ} \mathrm{N}, 138.48^{\circ} \mathrm{E}\right)$. The Köppen climate classification belongs to the Cfa. Figure 1 shows the outdoor climate in Saku City from January 6 to February 23. The outside air temperature during the measurement period ranged from $-5.1^{\circ} \mathrm{C}$ to $15.0^{\circ} \mathrm{C}$, and the average value was $4.2^{\circ} \mathrm{C}$. It was a cold environment where the outside air temperature is $0{ }^{\circ} \mathrm{C}$ or less. The relative humidity of the outside air varied in the range of $19-87 \%$, with an average value of $50.1 \%$. Table 1 shows the characteristics of the target detached house. Figure 2 shows the first-floor, second-floor, and foundation plans, in addition to an example of insulation placement.
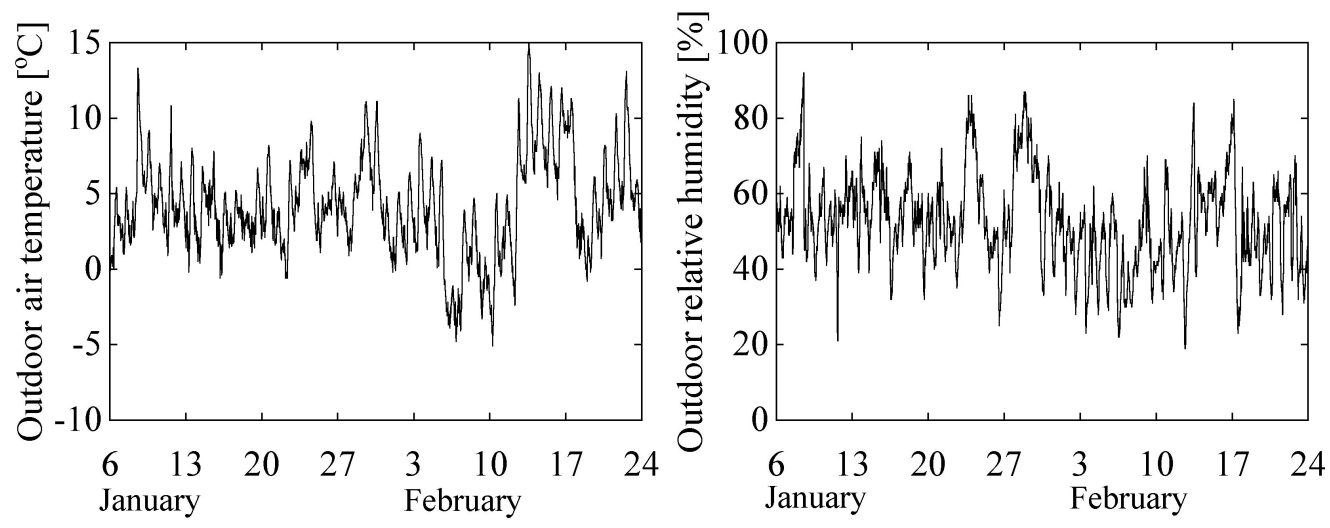

Figure 1. Outdoor air temperature and relative humidity in Saku City during the measurement period.

Table 1. The characteristics of the target detached house.

\begin{tabular}{|c|c|c|}
\hline \multicolumn{2}{|c|}{ Construction } & Two-Story Wooden Structure \\
\hline \multicolumn{2}{|c|}{ Total floor area } & $132.25 \mathrm{~m}^{2}$ \\
\hline \multicolumn{2}{|c|}{ First-floor area } & $75.56 \mathrm{~m}^{2}$ \\
\hline \multicolumn{2}{|c|}{ Second-floor area } & $56.69 \mathrm{~m}^{2}$ \\
\hline \multirow{6}{*}{ Insulation } & Wall & $\begin{array}{l}\text { Glass wool }(\mathrm{t}=100 \mathrm{~mm}) \\
\text { Phenol foam }(\mathrm{t}=30 \mathrm{~mm})\end{array}$ \\
\hline & Roof & Glass wool $(\mathrm{t}=300 \mathrm{~mm})$ \\
\hline & Foundation & Polystyrene foam $(\mathrm{t}=100 \mathrm{~mm})$ \\
\hline & Window & Low-E triple glass (Filled with Argon gas) \\
\hline & Sash & Resin sash \\
\hline & $\mathrm{U}_{\mathrm{A}}$ value & $0.29 \mathrm{~W} \cdot \mathrm{m}^{2} / \mathrm{K}$ \\
\hline
\end{tabular}



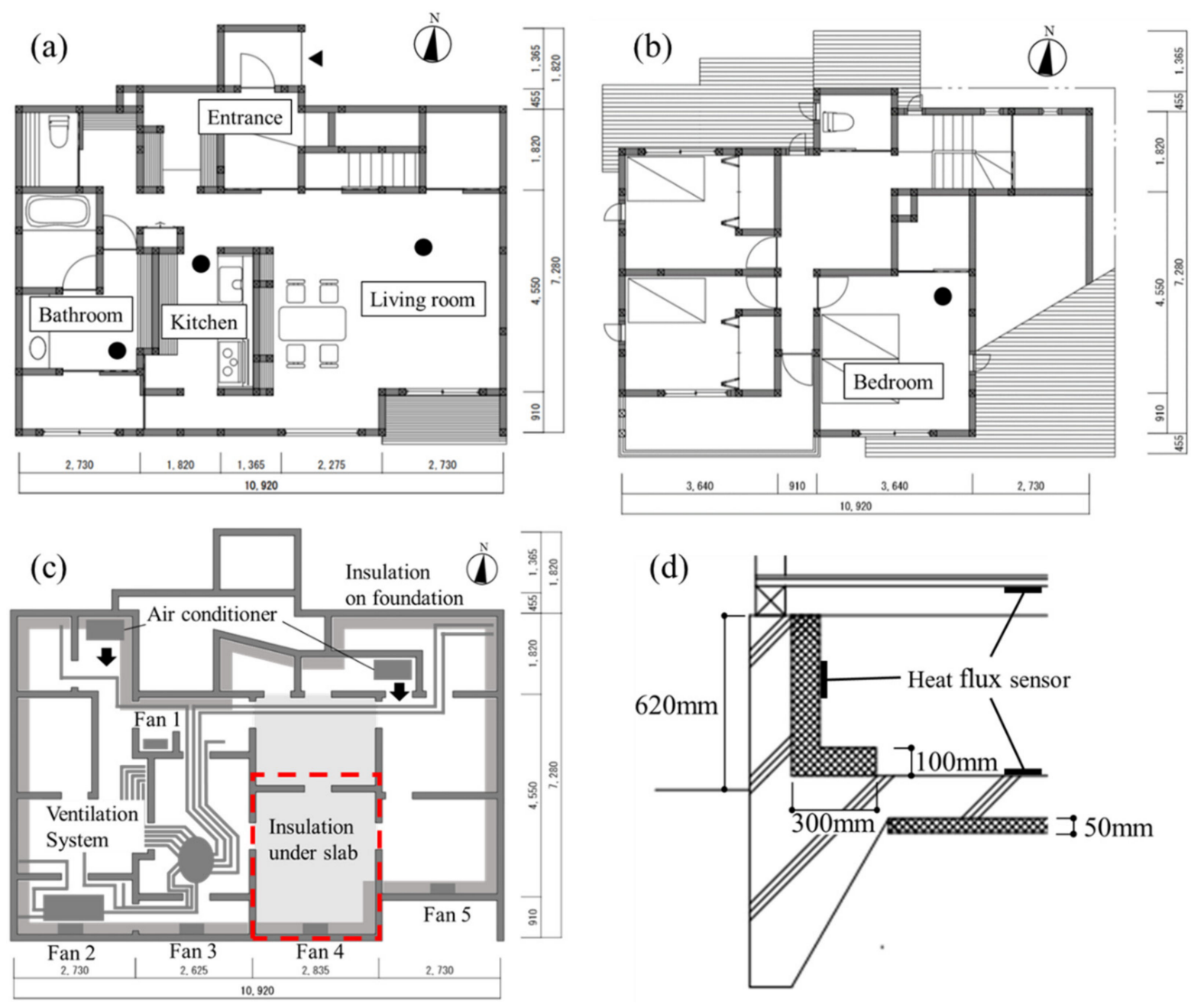

Figure 2. (a) First-floor plan, (b) Second-floor plan, (c) Foundation plan, (d) Insulation layout example: The measurement points of the indoor thermal environment are shown in $(\mathbf{a}, \mathbf{b})$. In $(\mathbf{c})$, the analysis range is shown by the red dashed line.

The air conditioning equipment comprises two room air conditioners and a ventilation system. These were installed on the floor. Room air conditioners obtain heat by using air heat source heat pumps. Table 2 lists the rated performance of the room air conditioner and ventilation system. Figure 3 shows the air circulation path during the crawl space heating. The floor consists of a 24-mm-thick structural plywood base and a 12-mm-thick wood finish. The floor on the first floor is not insulated.

Table 2. Performance of air conditioner and ventilation system.

\section{Heating capacity (I)}

Power consumption (II)

Air Conditioner

Ventilation System
Heating capacity (low temperature) (III)

Power consumption (low temperature) (IV)

Heating capacity (extremely low temperature) Annual performance factor (APF)

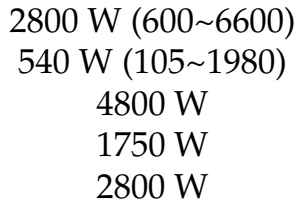

$2800 \mathrm{~W}(600 \sim 6600)$

$540 \mathrm{~W}(105 \sim 1980)$

$4800 \mathrm{~W}$

$1750 \mathrm{~W}$

$2800 \mathrm{~W}$

5.9

$145 \mathrm{~m}^{3} / \mathrm{h}$

$154 \mathrm{~m}^{3} / \mathrm{h}$ 


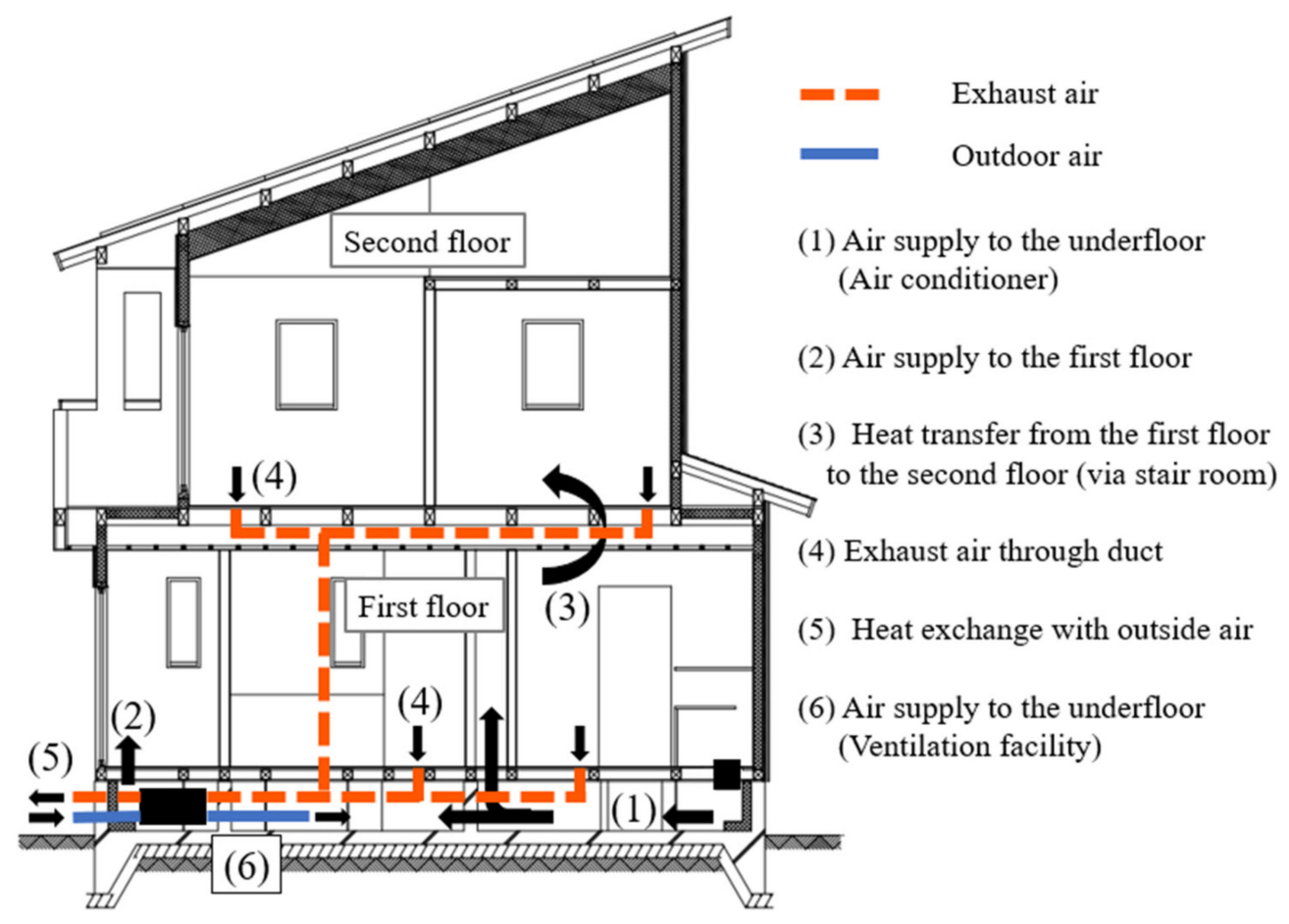

Figure 3. Airflow when using the crawl space heating.

\subsection{Room Air Conditioner}

\subsubsection{Coefficient of Performance}

The operating performance of a room air conditioner is expressed using the COP. The COP during heating was calculated as:

$$
\mathrm{COP}=q / P
$$

where $q$ and $P$ denote the rated heat capacity (W) and rated power consumption (W), respectively. The rated COP is 5.2, under standard conditions from (I) and (II) in Table 2. The heat quantity during practical operation was calculated as follows:

$$
q=Q \cdot \rho \cdot\left(E_{1}-E_{2}\right)
$$

where $q, Q, \rho, E_{1}$, and $E_{2}$ denote the heat capacity $(\mathrm{W})$, air flow rate $\left(\mathrm{m}^{3} / \mathrm{s}\right)$, density of air $\left(\mathrm{kg} / \mathrm{m}^{3}\right)$, enthalpy of blown air $(\mathrm{J} / \mathrm{kg})$, and enthalpy of suction air $(\mathrm{J} / \mathrm{kg})$, respectively. In order to calculate the enthalpy, the air temperature, relative humidity, and air velocity of the air outlet and suction port were measured. Table 3 lists the characteristics of the measurement equipment. The relationship between the measured air flow rate and air velocity is given as:

$$
Q=0.1524 v+0.00251(v>0)
$$

where $Q$ and $v$ denotes the air flow rate $\left(\mathrm{m}^{3} / \mathrm{s}\right)$ and measured air velocity $(\mathrm{m} / \mathrm{s})$, respectively. For the power consumption of the air conditioner, the data recorded in the Home Energy Management System (HEMS) were used.

\subsubsection{Overview of Air Source Heat Pump}

Frosting occurs on the evaporator when operating the air source heat pump in winter, which can cause the indoor temperature to decrease. The refrigerant temperature was measured to estimate the start time of the defrost operation. The measurement day was 15 December 2019.

Figure 4 shows the heat pump system diagram and refrigerant temperature measurement points, and the arrows in Figure 4 indicate the direction in which the refrigerant flows 
during the heating operation. During the heating operation, the refrigerant temperature of $T_{2}$ was high, and the refrigerant temperature of $T_{5}$ was low. The refrigerant flow in the defrost operation is opposite to that during the heating operation. It is estimated that the defrost operation occurred when the refrigerant temperature of $T_{2}$ changed from high temperature to low temperature, and the refrigerant temperature of $T_{5}$ changed from low temperature to high temperature.

Table 3. The characteristics of measurement equipment.

\begin{tabular}{|c|c|c|c|c|}
\hline Measurement Item & Equipment & Resolution & Accuracy & Manufacture \\
\hline Air temperature & Thermo recorder RTR-503 & & & \\
\hline Globe temperature & Thermo recorder TR-71 wf & $0.1^{\circ} \mathrm{C}$ & $\pm 0.3^{\circ} \mathrm{C}$ & T\&D corporation \\
\hline Relative humidity & Thermo recorder RTR-503 & $1 \%$ & $5 \%$ & \\
\hline Air velocity & $\begin{array}{c}\text { Climomaster } 6501 \\
\text { Climomaster 6541-21 }\end{array}$ & $0.01 \mathrm{~m} / \mathrm{s}$ & $\pm 0.02 \mathrm{~m} / \mathrm{s}$ & $\begin{array}{l}\text { Nihon Kanomax } \\
\text { corporation }\end{array}$ \\
\hline Heat flux & $\begin{array}{l}\text { Heat flux sensor } \\
(50 \mathrm{~mm} \times 50 \mathrm{~mm})\end{array}$ & - & - & $\begin{array}{l}\text { Etodenki } \\
\text { corporation }\end{array}$ \\
\hline
\end{tabular}

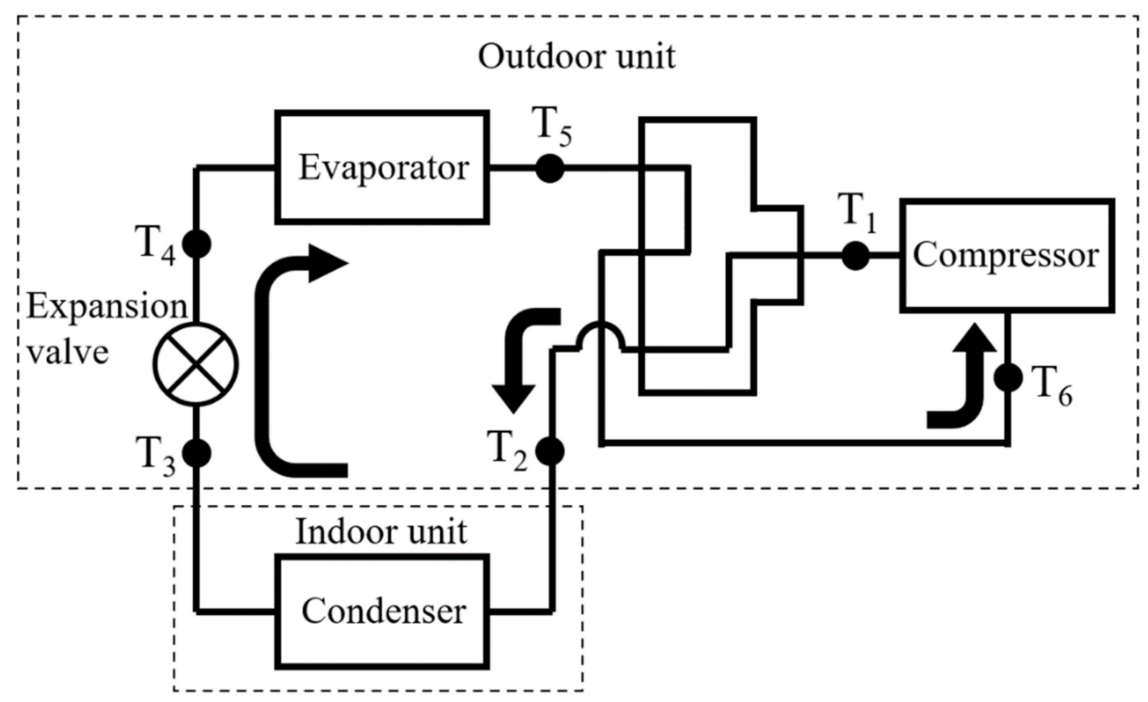

Figure 4. System diagram of air source heat pump.

\subsection{Indoor Environment Survey}

\subsubsection{Indoor Thermal Environment Measurement}

The indoor thermal environment was measured between 6 January and 26 February 2020 . The measurement parameters were air temperature, relative humidity, globe temperature, and air velocity. Figure 2 shows the measurement points in the room. The measurement points were the living room, kitchen, bathroom, and bedroom. Table 3 lists the characteristics of the measurement equipment used. The globe temperature was measured using a hollow copper ball with a diameter of $150 \mathrm{~mm}$. The sphere was painted black, and the emissivity was 0.95 . The measurement heights of the air temperature were $0.1 \mathrm{~m}$ and $1.1 \mathrm{~m}$ above the floor. The measurement height of relative humidity and globe temperature were both $1.1 \mathrm{~m}$ above the floor. An omnidirectional hot-wire anemometer was used to measure air velocity. The measurement height of the air velocity was $1.1 \mathrm{~m}$ above the floor.

\subsubsection{Questionnaire}

Subjective surveys were conducted on 25 and 26 January 2020. The survey time was between 10:00 and 16:00, and the targets were visitors to a detached house. A questionnaire was used for the subjective survey. The survey was conducted on visitors who understood the contents of the questionnaire and obtained their consent. Table 4 shows the age group 
of subjects. The study included 45 men and 62 women. The scales used for the subjective surveys were prepared based on ISO10551 [40] and ASHRAE Standard 55 [1]. Table 5 summarizes the items related to thermal comfort. The questionnaire was created with reference to the Japanese translation defined by the Architectural Institute of Japan [41] based on ASHRAE Standard 55 [1] and ISO 10551 [40]. Table 6 shows the clothing option. The options were prepared based on the ASHRAE Fundamental 2013 [42], and a free response column was added.

Table 4. The age group of subjects.

\begin{tabular}{cccccccc}
\hline & $\mathbf{1 0 s}$ & $\mathbf{2 0 s}$ & $\mathbf{3 0 s}$ & $\mathbf{4 0 s}$ & $\mathbf{5 0 s}$ & $\mathbf{6 0 s}$ & Total \\
\hline Male & 3 & 6 & 20 & 6 & 5 & 5 & 45 \\
Female & 0 & 13 & 27 & 8 & 8 & 6 & 62 \\
\hline
\end{tabular}

Table 5. Subjective survey content.

\begin{tabular}{ccccc}
\hline Thermal Sensation & $\begin{array}{c}\text { Thermal Sensation } \\
\text { (Ankle Level) }\end{array}$ & Affective Evaluation & Thermal Preference & $\begin{array}{c}\text { Personal } \\
\text { Acceptability }\end{array}$ \\
\hline +3: hot & $+3:$ hot & 0: comfortable & $+1:$ warmer & $0:$ acceptable \\
+2: warm & $+2:$ warm & -1 : slightly uncomfortable & 0: no change & $-1:$ not acceptable \\
+1: slightly warm & + 1: slightly warm & $-2:$ uncomfortable & $-1:$ cooler & \\
0: neutral & 0: neutral & $-3:$ very uncomfortable & \\
-1: slightly cool & $-1:$ slightly cool & $-4:$ extremely uncomfortable & & \\
-2: cool & $-2:$ cool & & \\
-3: cold & $-3:$ cold & & \\
\hline
\end{tabular}

Table 6. Clothing option and clothing insulation, $\mathrm{I}_{\mathrm{cl}}$.

\begin{tabular}{cccccc}
\hline Option & $\mathbf{I}_{\mathbf{c l}}$ (clo) & Option & $\mathbf{I}_{\mathbf{c l}}$ (clo) & Option & $\mathbf{I}_{\mathbf{c l}}$ (clo) \\
\hline T-shirt & 0.08 & Knee sock (thick) & 0.06 & Walking shorts & 0.08 \\
Long underwear top & 0.20 & Panty hose & 0.02 & Straight trousers (thin) & 0.15 \\
Long underwear bottoms & 0.15 & Sleeveless, scoop-neck blouse & 0.12 & Straight trousers (thick) & 0.24 \\
Skirt (thin) & 0.14 & Short-sleeved, dress shirt & 0.19 & Sweatpants & 0.28 \\
Skirt (thick) & 0.23 & Short-sleeved, knit sport shirt & 0.17 & Overalls & 0.30 \\
Sleeveless, scoop neck (thin) & 0.23 & Long-sleeved, dress shirt & 0.25 & Sleeveless vest (thin) & 0.10 \\
Sleeveless, scoop neck (thick) & 0.27 & Long-sleeved, flannel shirt & 0.34 & Sleeveless vest (thick) & 0.17 \\
Short-sleeved shirtdress (thin) & 0.29 & Long-sleeved, sweatshirt & 0.34 & Single-breasted (thin) & 0.36 \\
Long-sleeved shirtdress (thin) & 0.33 & Sleeveless vest (thin) & 0.13 & Single breasted (thick) & 0.44 \\
Long-sleeved shirtdress (thick) & 0.47 & Sleeveless vest (thick) & 0.22 & Double-breasted (thin) & 0.42 \\
Ankle-length athletic socks & 0.02 & Long-sleeved (thin) & 0.25 & Double-breasted (thick) & 0.48 \\
Calf-length socks & 0.03 & Long-sleeved (thick) & 0.36 & (Free description) & \\
\hline
\end{tabular}

In this study, the relationship between thermal sensation and operative temperature was analyzed. The operative temperature can be calculated as follows [43]:

$$
t_{o}=\frac{h_{r} \overline{t_{r}}+h_{c} t_{a}}{h_{r}+h_{c}}
$$

where $t_{0}, \overline{t_{r}}, t_{a}, h_{r}$, where $h_{c}$ denotes the operative temperature $\left({ }^{\circ} \mathrm{C}\right)$, mean radiant temperature $\left({ }^{\circ} \mathrm{C}\right)$, ambient air temperature $\left({ }^{\circ} \mathrm{C}\right)$, radiative heat transfer coefficient $\left(\mathrm{W} /\left(\mathrm{m}^{2} \cdot \mathrm{K}\right)\right)$, and convection heat transfer coefficient $\left(\mathrm{W} /\left(\mathrm{m}^{2} \cdot \mathrm{K}\right)\right)$.

The equation for calculating the convective heat transfer coefficient $\left(h_{c}\right)$ is based on the air velocity. In this study, the equation derived by Mitchell [42] was used:

$$
\begin{array}{cc}
h_{c}=3.1 & 0.2<V<1.5 \\
h_{c}=8.3 V^{0.6} & 0<V<0.2
\end{array}
$$


The radiative heat transfer coefficient $(h)$ was calculated by multiplying the average emissivity of clothing or body surface $(\varepsilon=0.95)$ by 4.7 [42]:

$$
h_{r}=4.7 \varepsilon
$$

The mean radiant temperature was calculated from the air temperature, globe temperature, and air velocity using the following [43]:

$$
\overline{t_{r}}=\left[\frac{6.32 D^{-0.4} V^{0.5}}{\sigma \mathcal{E}}\left(t_{g}-t_{a}\right)+t_{g}^{4}\right]^{0.25}
$$

where $\varepsilon$ denotes the emissivity of the globe sphere surface (0.95) and D represents the diameter of the globe sphere $(0.15 \mathrm{~m})$.

Neutral temperature is the temperature at which the subject feels thermally neutral. In this study, the regression equation was calculated using the linear regression method; however, the difference was not significant $(p>0.05)$. Therefore, the neutral temperature was calculated using the Griffith method. The neutral temperature was calculated as follows:

$$
t_{n}=t_{o}-\frac{\left(T S V-T S V_{\text {neutral }}\right)}{a}
$$

where $t_{n}, t_{0}, T S V, T S V_{\text {neutral }}$, and $a$ denote the neutral temperature $\left({ }^{\circ} \mathrm{C}\right)$, operative temperature $\left({ }^{\circ} \mathrm{C}\right)$, thermal sensation vote, neutral thermal sensation $(T S V=0)$, and coefficient $(0.33,0.5)$, respectively. In Section $3, t_{n}$ with a coefficient of 0.33 is represented by $t_{n(0.33)}$ and that with a coefficient of 0.5 is represented by $t_{n(0.5)}$.

\subsection{Crawl Space Environment Survey}

The air temperature in crawl space was measured to determine if the heating air was sufficiently distributed in the crawl space; the measurement period was between 6 January and 26 February 2020. A portable data logger was used to measure air temperature. Table 3 lists the characteristics of the portable data logger. Figure 5 a shows the measurement points of the air temperature. The measurement height of the air temperature was set to $300 \mathrm{~mm}$ above the foundation slab surface.
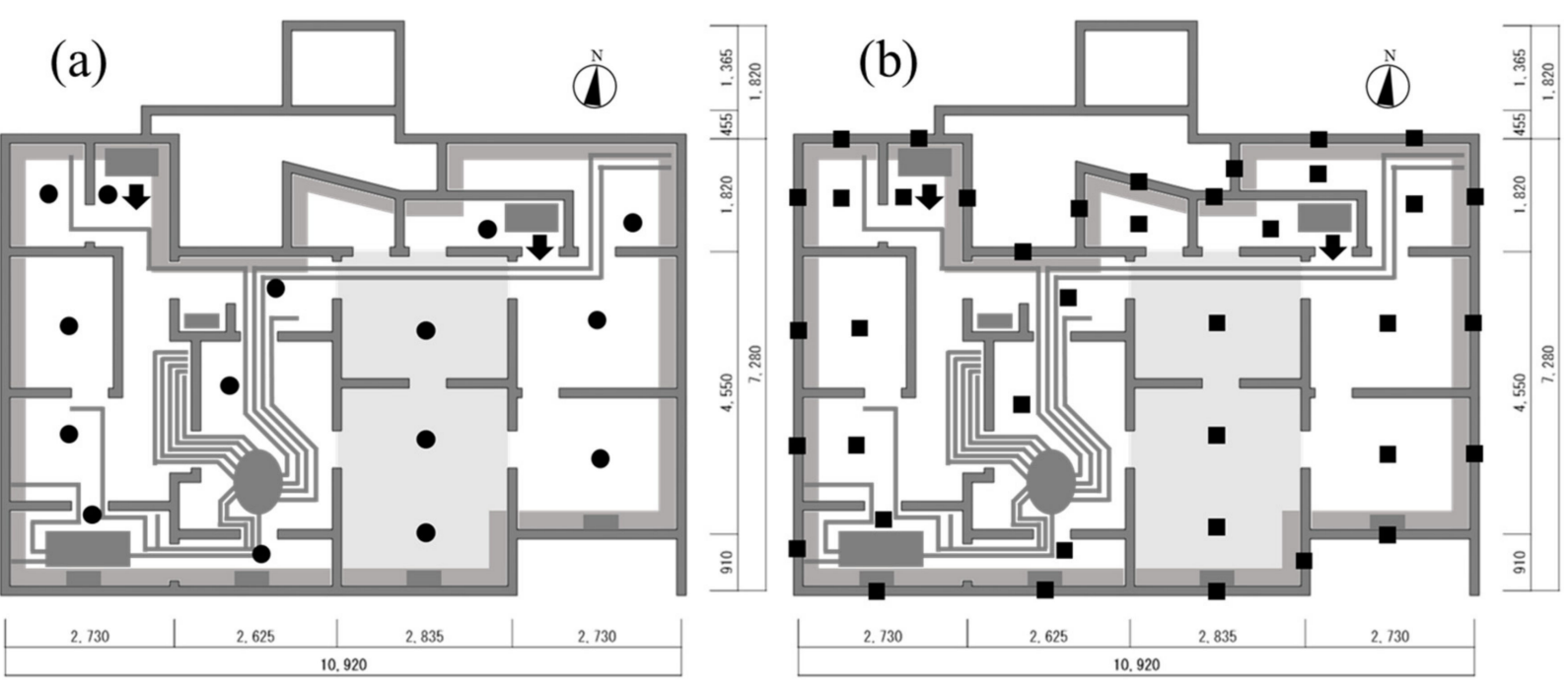

Figure 5. The measure points, (a) crawl space air temperature, (b) heat flux generated on the surface of foundation slabs, foundation walls, and first floors.

The heat transferred from the crawl space was measured; the measurement period was from 27 January to 2 February 2020. The heat transfer directions include the foundation slab, foundation wall, first floor, and fan. Figure $5 \mathrm{~b}$ shows the heat flux measurement 
points. Table 3 lists the characteristics of heat flux sensors. The heat transfer through the fan was calculated using the follow equation:

$$
q=c_{p} \times \rho \times V \times\left(\theta_{\text {crawl space }}-\theta_{\text {indoor }}\right)
$$

where $q, c_{p}, \rho, V, \theta_{\text {crawl space }}$, and $\theta_{\text {indoor }}$ denote the heat transfer from the fan $(\mathrm{W})$, specific heat of air $1005(\mathrm{~J} / \mathrm{kg} \cdot \mathrm{K})$, density of air $1.2\left(\mathrm{~kg} / \mathrm{m}^{3}\right)$ air flow rate $\left(\mathrm{m}^{3} / \mathrm{s}\right)$, crawl space air temperature $\left({ }^{\circ} \mathrm{C}\right)$, and Indoor air temperature $\left({ }^{\circ} \mathrm{C}\right)$, respectively.

\subsection{Insulation Placement Analysis}

The analysis program WUFI2D 4.2, by EI, Ltd. (Minato-ku, Tokyo), was used to examine the effect of suppressing heat loss caused by a change in insulation placement.

The analysis model was created based on the target detached house. Figure 6 shows the analysis model. The red dashed line in Figure $2 \mathrm{c}$ indicates the analysis range. Table 7 summarizes the components and their physical characteristics.

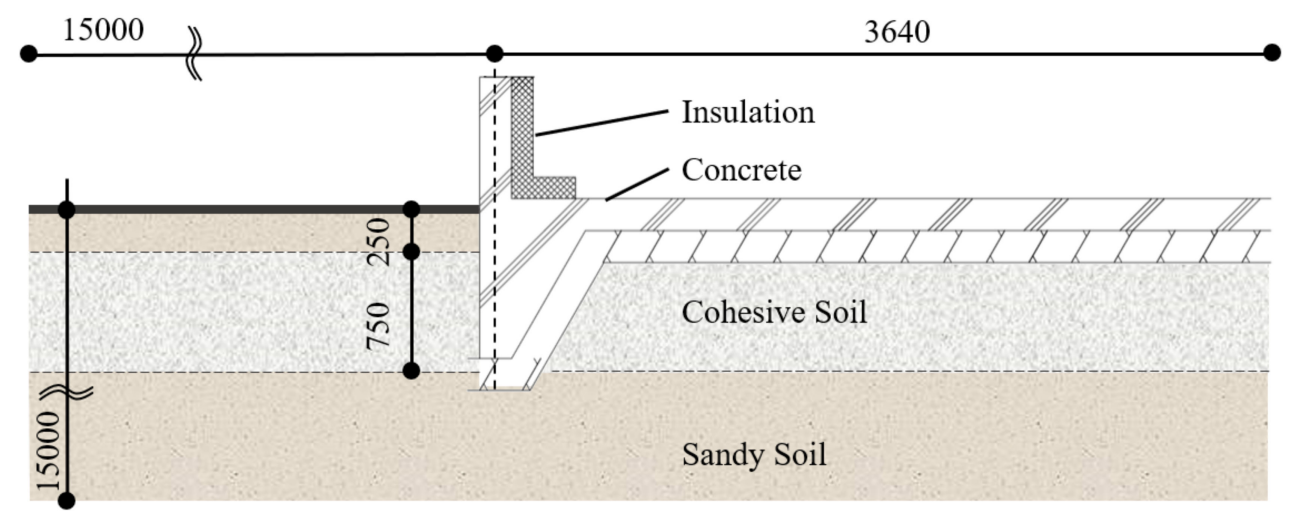

Figure 6. Analytical model created based on the detached house to be studied.

Table 7. Components and physical properties.

\begin{tabular}{cccc}
\hline & Density $\left(\mathbf{k g} / \mathbf{m}^{\mathbf{3}}\right)$ & $\begin{array}{c}\text { Specific Heat } \\
(\mathbf{J} / \mathbf{k g} \cdot \mathbf{K})\end{array}$ & $\begin{array}{c}\text { Thermal Conductivity } \\
\mathbf{( W / m} \cdot \mathbf{K})\end{array}$ \\
\hline Insulation & 28.6 & 1470 & 0.025 \\
Concrete & 2220.0 & 850 & 1.600 \\
Sandy soil & 1507.0 & 850 & 0.488 \\
Cohesive soil & 1361.0 & 850 & 0.350 \\
\hline
\end{tabular}

Meteorological conditions attributed to the outdoor surface were obtained using the Automated Meteorological Data Acquisition System (AMeDAS) managed by the Japan Meteorological Agency. Table 8 summarizes the conditions of the indoor surfaces. The total heat transfer coefficient is defined as the sum of the radiant heat transfer coefficient and convective heat transfer coefficient, and the surface temperature had the minimum and maximum values of 1 August and 1 February, respectively.

In this study, the convective heat transfer coefficient was calculated based on the Jurges formula [44]:

$$
\begin{array}{cc}
\alpha_{c v}=5.6+3.9 v & v \leq 4.9 \mathrm{~m} / \mathrm{s} \\
\alpha_{c v}=7.2 v^{0.78} & v>4.9 \mathrm{~m} / \mathrm{s}
\end{array}
$$

where $\alpha_{c v}$ and $v$ denote the convective heat transfer coefficient $\left(\mathrm{W} / \mathrm{m}^{2} \cdot \mathrm{K}\right)$ and air velocity $(\mathrm{m} / \mathrm{s})$, respectively. 
Table 8. Surface conditions of components.

\begin{tabular}{|c|c|c|c|c|c|c|c|c|}
\hline $\begin{array}{l}\text { Distance from the } \\
\text { Foundation Wall (mm) }\end{array}$ & $0-455$ & $455-910$ & 910-1365 & $1365-1820$ & $1820-2275$ & $2275-2730$ & 2730-3185 & $3185-3640$ \\
\hline $\begin{array}{l}\text { Convection heat transfer } \\
\text { coefficient }\left(\mathrm{W} / \mathrm{m}^{2} \cdot \mathrm{K}\right)\end{array}$ & 6.38 & 5.99 & 5.99 & 7.94 & 7.16 & 5.6 & 6.77 & 5.99 \\
\hline $\begin{array}{l}\text { Radiant heat transfer } \\
\text { coefficient }\left(\mathrm{W} / \mathrm{m}^{2} \cdot \mathrm{K}\right)\end{array}$ & 5.04 & 5.04 & 5.04 & 5.04 & 5.11 & 5.11 & 5.11 & 5.11 \\
\hline $\begin{array}{l}\text { Heat transfer coefficient } \\
\qquad\left(\mathrm{W} / \mathrm{m}^{2} \cdot \mathrm{K}\right)\end{array}$ & 11.4 & 11.0 & 11.0 & 13.0 & 12.3 & 10.7 & 11.9 & 11.1 \\
\hline Surface temperature $\left({ }^{\circ} \mathrm{C}\right)$ & \multicolumn{4}{|c|}{$\begin{array}{c}\text { Sine wave } \\
\text { Minimum } 22^{\circ} \mathrm{C}(1 \text { August }), \\
\text { Maximum } 32{ }^{\circ} \mathrm{C} \text { (1 February) }\end{array}$} & \multicolumn{4}{|c|}{$\begin{array}{c}\text { Sine wave } \\
\text { Minimum } 22{ }^{\circ} \mathrm{C}(1 \text { August }), \\
\text { Maximum } 34{ }^{\circ} \mathrm{C}(1 \text { February })\end{array}$} \\
\hline
\end{tabular}

The analysis was performed using CFD simulation software (Flow Designer academic 2020; Advanced Knowledge Laboratory Inc.) because the air velocity in the crawl space was not measured. An area was created for the analysis $(10,920 \mathrm{~mm}$ (width) $\times 7280 \mathrm{~mm}$ (depth) $\times 600 \mathrm{~mm}$ (height), and the foundation plan was modeled as illustrated in Figure 2c. The blowout area for the room air conditioner was $600 \mathrm{~mm} \times 50 \mathrm{~mm}$; it was $260 \mathrm{~mm} \times 60 \mathrm{~mm}$ for the fans and $150 \mathrm{~mm}$ in diameter for the ventilation system. Based on the field study, the air flow rates were $540 \mathrm{~m}^{3} / \mathrm{h}, 58 \mathrm{~m}^{3} / \mathrm{h}, 76 \mathrm{~m}^{3} / \mathrm{h}, 86 \mathrm{~m}^{3} / \mathrm{h}, 72 \mathrm{~m}^{3} / \mathrm{h}$, and $68 \mathrm{~m}^{3} / \mathrm{h}$ for room air conditioners, fans $1,2,3,4$, and 5 , respectively. The air flow rate of the ventilation system was set to $145 \mathrm{~m}^{3} / \mathrm{h}$, as listed in Table 2 . An opening was created as appropriate because there was a gap in the installation position of the room air conditioners. The convective heat transfer coefficient was obtained by substituting the air velocity obtained by steady-state analysis into the Equation (10).

In this study, the radiant heat transfer coefficient was calculated based on the radiant heat exchange between two parallel planes [45]. The radiant heat flux from the surface of the object is expressed as:

$$
q_{r}=\varepsilon \sigma T^{4}
$$

where $q_{r}, \varepsilon, \sigma$, and $T$ denote the radiant heat transfer $\left(\mathrm{W} / \mathrm{m}^{2}\right)$, emissivity $0.9(-)$, StefanBoltzmann constant $5.67 \times 10^{-8}\left(\mathrm{~W} / \mathrm{m}^{2} \cdot \mathrm{K}^{4}\right)$, and surface temperature $(\mathrm{K})$, respectively. Furthermore, Equation (11) is approximated as:

$$
q_{r}=\varepsilon \sigma T^{4}=a T+b
$$

Differentiating both sides of $T$ yields $a=4 \varepsilon \sigma T^{3}$. The calculation process when the surface temperature of the member is assumed to be $30{ }^{\circ} \mathrm{C}$ is shown; by substituting $T=303.15 \mathrm{~K}, a=5.68$ and $b=-1290.38$. Furthermore, the emissivity of general building materials was 0.90 . Therefore:

$$
\begin{gathered}
\varepsilon_{\text {basement slab }}=\varepsilon_{\text {plywood }}=0.90 \\
a_{\text {basement slab }}=a_{\text {plywood }}=5.68 \\
b_{\text {basement slab }}=b_{\text {plywood }}=-1290.38
\end{gathered}
$$

The radiant heat exchange between two parallel planes is expressed by:

$$
\overline{q_{r}}=\frac{\sigma\left(T_{1}^{4}-T_{2}^{4}\right)}{\frac{1}{\varepsilon_{1}}+\frac{1}{\varepsilon_{2}}-1}
$$

where $\overline{q_{r}}, T_{1}, T_{2}, \varepsilon_{1}$, and $\varepsilon_{2}$ denote the radiant heat exchange $\left(\mathrm{W} / \mathrm{m}^{2}\right)$, surface temperature of the foundation slab $(\mathrm{K})$, surface temperature of the first-floor $(\mathrm{K})$, emissivity of the foundation slab surface (0.90) (-), and emissivity of the first floor (structural plywood) (0.90) (-).

From Equations (13) and (14):

$$
\overline{q_{r}}=\frac{\sigma}{\frac{1}{\varepsilon_{\text {basement slab }}}+\frac{1}{\varepsilon_{\text {plywood }}}-1} \times\left(\frac{a_{\text {basement slab }} \cdot T_{1}+b_{\text {basement slab }}}{\varepsilon_{\text {basement slab }} \cdot \sigma}-\frac{a_{\text {plywood }} \times T_{2}+b_{\text {plywood }}}{\varepsilon_{\text {plywood }} \times \sigma}\right)
$$


Substituting each value in Equation (15):

$$
\begin{gathered}
\overline{q_{r}}=\frac{\sigma}{\frac{1}{0.9}+\frac{1}{0.9}-1} \times\left(\frac{5.68 \times T_{1}-1290.38}{0.9 \cdot \sigma}-\frac{5.68 \times T_{2}-1290.38}{0.9 \cdot \sigma}\right) \\
\overline{q_{r}}=\frac{1}{\frac{1}{0.9}+\frac{1}{0.9}-1} \times \frac{5.68}{0.9} \times\left(T_{1}-T_{2}\right) \\
\overline{q_{r}}=5.16 \times\left(T_{1}-T_{2}\right)
\end{gathered}
$$

According to Equation (16), the radiant heat transfer coefficient $\alpha_{r}$ is 5.16.

The analysis model was based on the insulation placement assumed in Japanese detached housing. Table 9 summarizes the types of analysis models used. The original shows the insulation placement of the detached house under study. Case 1 represents a condition wherein a 100-mm-thick horizontal insulation was placed on the foundation slab and extended. Case 2 indicates a condition wherein the horizontal insulation with a thickness of $100 \mathrm{~mm}$ was placed under the foundation slab and extended. Case 3 indicates a condition wherein the skirt insulation was extended by placing a 100-mm-thick vertical insulation on the outside of the foundation wall. The heat transfer coefficient of each insulation was $0.025 \mathrm{~W} / \mathrm{m} \cdot \mathrm{K}$.

Table 9. Insulation placement and dimensions.

\begin{tabular}{ccccc}
\hline & Original & Case1 & Case2 & \\
Model & & & \\
& & &
\end{tabular}

\section{Results and Discussion}

\subsection{Evaluation of Room Air Conditioner}

\subsubsection{Operation Performance}

When heating using an air source heat pump, frost may form on the evaporator, which can reduce its heat exchange capacity. Moreover, the heating stop efficiency is lowered because of the defrosting operation. Based on interviews with the manufacturer, it was found that $50 \mathrm{~min}$ of heating operation and $10 \mathrm{~min}$ of defrost operation were performed when the outside air temperature dropped below $5{ }^{\circ} \mathrm{C}$. In response to the above, the power consumption, output heat, and COP were calculated to evaluate the operating performance during continuous operation. Figure 7 shows the operation characteristics; the maximum COP value was 5.5 , the minimum value was 0.6 , and the average value was 2.9 . Therefore, the room air conditioner operates efficiently.

The average values of power consumption, heat quantity, and COP were calculated for each outside air temperature of $0.5^{\circ} \mathrm{C}$ to understand the relationship between the outside air temperature and the operating characteristics. Figure 8 shows the relationship between the outside air temperature and operation characteristics. The COP decreased as the outside air temperature decreased.

Guo et al. [8] indicated that the heating capacity and COP decreased as the thickness of the frosting on the surface of the evaporator increased. Furthermore, it was shown that the air temperature range where the frost growth rate reached its maximum was approximately $0{ }^{\circ} \mathrm{C}$. In this study, the COP decreased in a temperature range earlier than the air temperature, as indicated by Guo et al. [8]. 

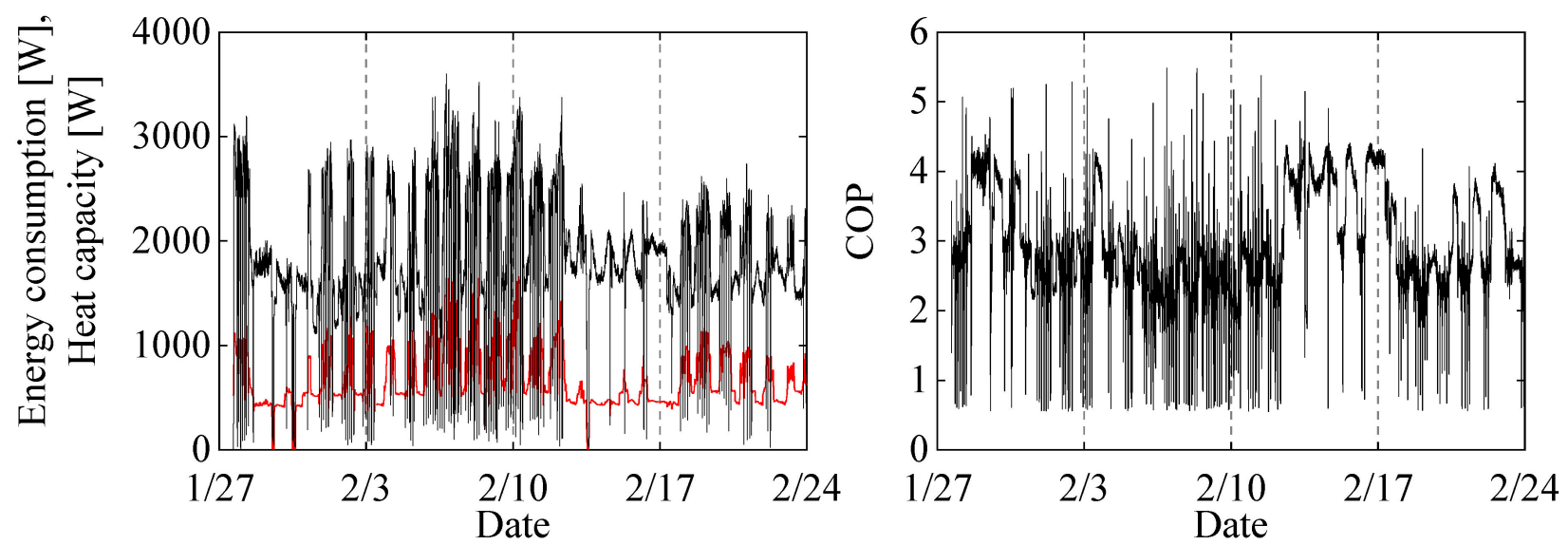

Figure 7. Operating characteristics of the room air conditioner during heating operation.
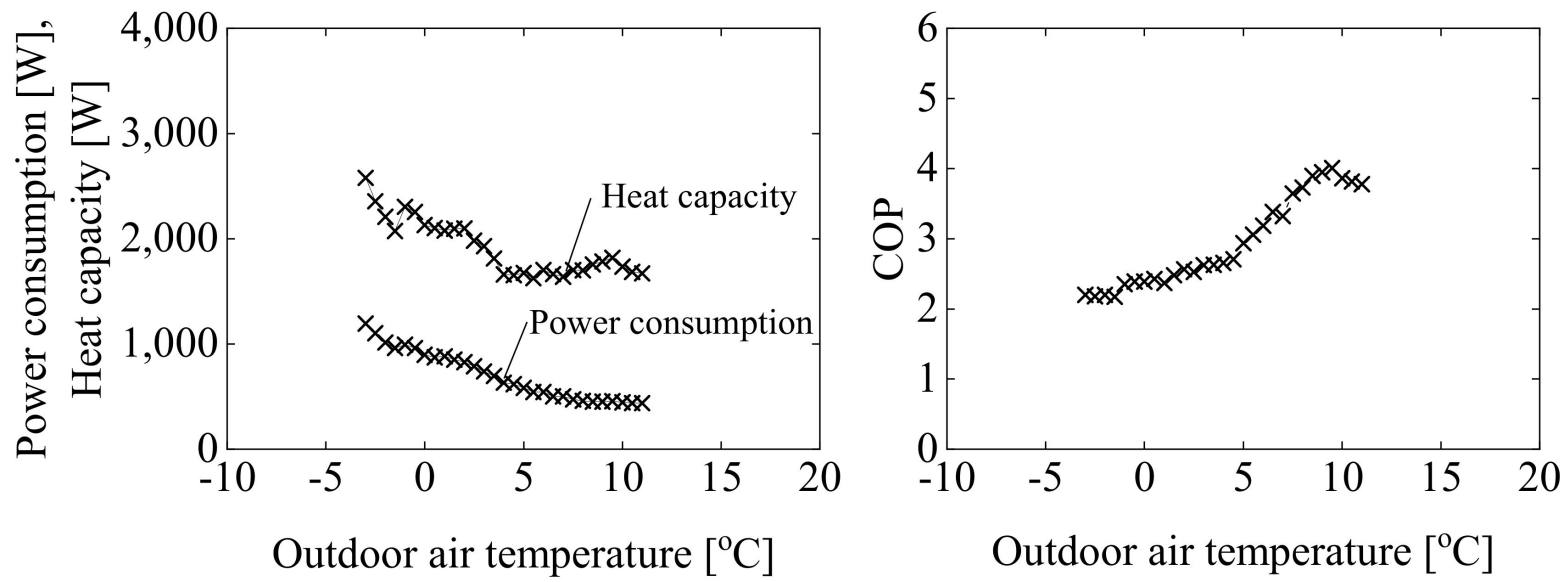

Figure 8. Relationship between outside air temperature and operating characteristics.

The operating characteristics of the room air conditioner were evaluated using a $\mathrm{p}-\mathrm{h}$ diagram. Figure 9 shows the refrigeration cycle on the $\mathrm{p}-\mathrm{h}$ diagram; the results in Figure 9 are the average values for 15 December 2019. The refrigerant pressure and enthalpy were estimated from the refrigerant temperature and calculated using the program software of the Japan Society of Refrigerator and Air Conditioning. The degree of subcooling was $5.7^{\circ} \mathrm{C}$, and the degree of superheating was $0.5^{\circ} \mathrm{C}$. According to the $\mathrm{p}-\mathrm{h}$ diagram, in the condenser, heat exchange took place between the refrigerant and the room air. The expansion valve regulated the refrigerant pressure. It can be determined that the refrigerant evaporates in the evaporator, and there is no possibility that the liquid refrigerant flows into the compressor. However, this study estimated the pressure and enthalpy from the refrigerant temperature, and it was pointed out that the estimated values differ from the measured values. Yamaguchi et al. [46] compared the measured refrigerant pressure and refrigerant pressure estimated from the refrigerant temperature. The measured refrigerant pressure in the condenser was higher than the estimated value, and the measured refrigerant pressure in the evaporator was lower than the estimated value. In the cycle shown in Figure 9, it is assumed that the range of high- and low-pressure widens. Yamaguchi et al. [46] reported that the COP can be improved by reducing the pressure to a value corresponding to the saturation temperature. 


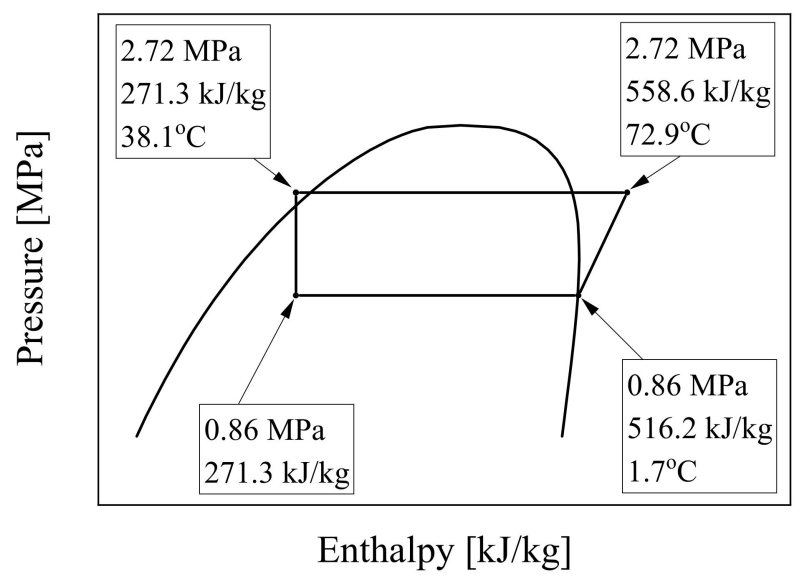

Figure 9. Refrigeration cycle estimated based on refrigerant temperature.

However, it is unclear if this can be applied to the heat pump of a room air conditioner. Therefore, there is room for examining the operation of the heat pump of a room air conditioner. Kocyigit et al. [47] used a $\mathrm{p}-\mathrm{h}$ diagram to diagnose cycle failures. The refrigerant may not evaporate completely if the heat transfer in the evaporator is interrupted. This causes the liquid-phase refrigerant to flow into the compressor. The liquefied refrigerant is recovered by the accumulator; however, there is a shortage of refrigerants that circulate in the cycle. The operating capacity decreases as the mass flow rate of the refrigerant decreases [47]. The decrease in the heat transfer capacity of the evaporator is caused by frost formation on the evaporator. The refrigerant pressure is reduced by passing through the expansion valve. The refrigerant temperature decreased as the pressure decreased. Figure 10 shows the relationship between the outside air temperature and refrigerant temperature in front of the evaporator in this study. When the outside air temperature is $6.2^{\circ} \mathrm{C}$, the refrigerant temperature is already $0{ }^{\circ} \mathrm{C}$ or less, and there is a possibility that frost has occurred on the evaporator. In the evaporator, the refrigerant temperature is lower than the outside air temperature. The conditions under which frost occurs change depending on the refrigerant temperature. Therefore, it is necessary to investigate the relationship between the outside air temperature and the refrigerant temperature and the control of the expansion valve.

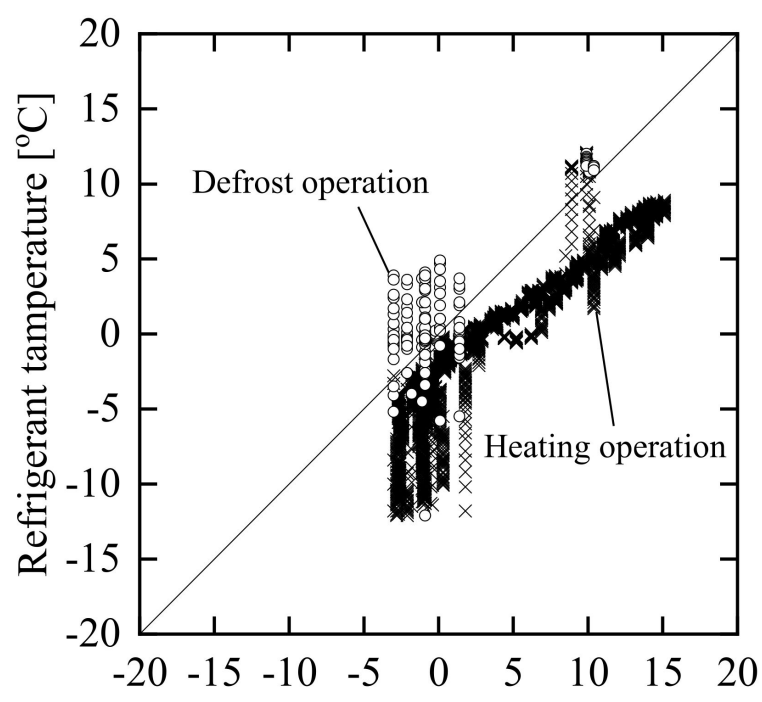

Outdoor air tempeature $\left[{ }^{\circ} \mathrm{C}\right]$

Figure 10. Relationship between outside air temperature and refrigerant temperature after passing through the expansion valve. 


\subsubsection{The Influence of Defrost Operation}

The heating air temperature, heat flux generated on the foundation slab surface, and indoor air temperature were measured to investigate the effect of indoor air temperature caused by the defrosting operation. Figure 11 shows the outside air temperature; it dropped below $0{ }^{\circ} \mathrm{C}$ in the morning, and then the outside air temperature increased. Figure 12 shows the measurement results, and Figure 12a shows the changes in the refrigerant temperature at $T_{2}$ and $T_{5}$. During the defrost operation, the refrigerant temperature of $T_{2}$ was low, and the refrigerant temperature of $T_{5}$ was high. Thus, the defrost operation was performed seven times. The cumulative time for defrosting was $64 \mathrm{~min}$ per day. Figure 12b shows the heating air temperature. The heating air temperature decreased because of the decrease in the refrigerant temperature at $\mathrm{T}_{2}$. Figure $12 \mathrm{c}$ shows the heat flux generated on the surface of the foundation slab. The positive values of heat flux indicate that heat was transferred from the foundation slab to the crawl space. The heat flux recorded a positive value when the heating air temperature became low; therefore, it was assumed that the air was warmed by the heat storage of the structure. Figure $12 \mathrm{~d}$ shows the indoor air temperature, and the indoor air temperature did not simultaneously change with the defrost operation; this shows a periodic change only in the indoor temperature caused by solar radiation.

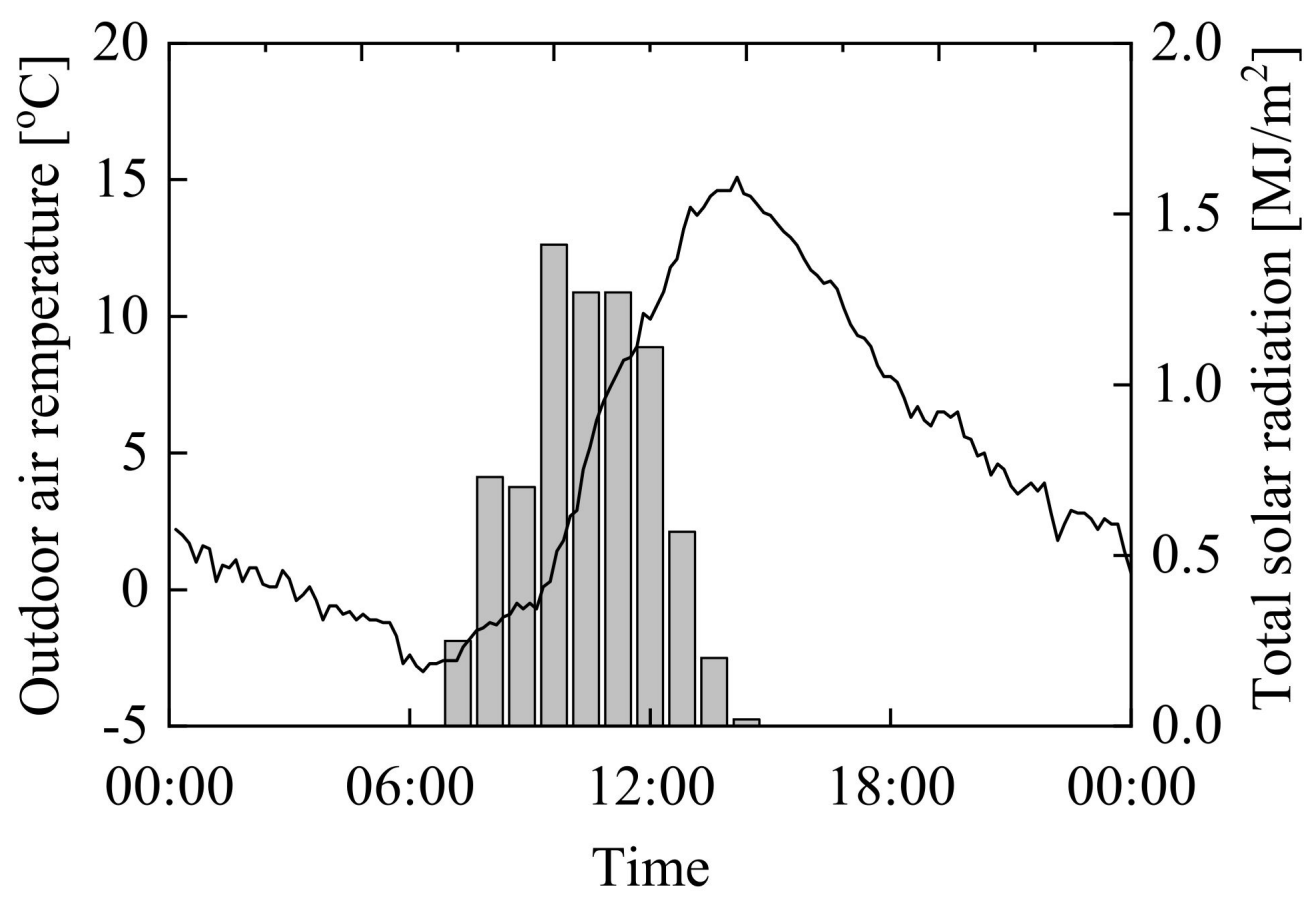

Figure 11. Outside air temperature and total solar radiation during the measurement period.

\subsection{Crawl Space Air Temperature Distribution}

The heating air must be distributed in the crawl space to ensure a uniform indoor temperature distribution. Therefore, the horizontal temperature distribution in the crawl space is measured. Figure 13 shows the air temperature in the crawl space. The air temperatures were calculated using the average values for two days, that is, 25 and 26 January 2020 . The lowest air temperature was $22.5^{\circ} \mathrm{C}$. The air temperature was low because this measurement point was close to the air supply port of the ventilation system. Other factors included the distance of the measurement point from the air conditioner and the high density of the piping of the air-conditioning equipment. On the east side, there were fewer equipment pipes than on the west side; thus, the heating air was well distributed. It is necessary to intersperse the air supply ports of the ventilation system to ensure a uniform air temperature distribution. However, complicated piping makes it difficult to diffuse air, which hinders uniform air temperature distribution. 

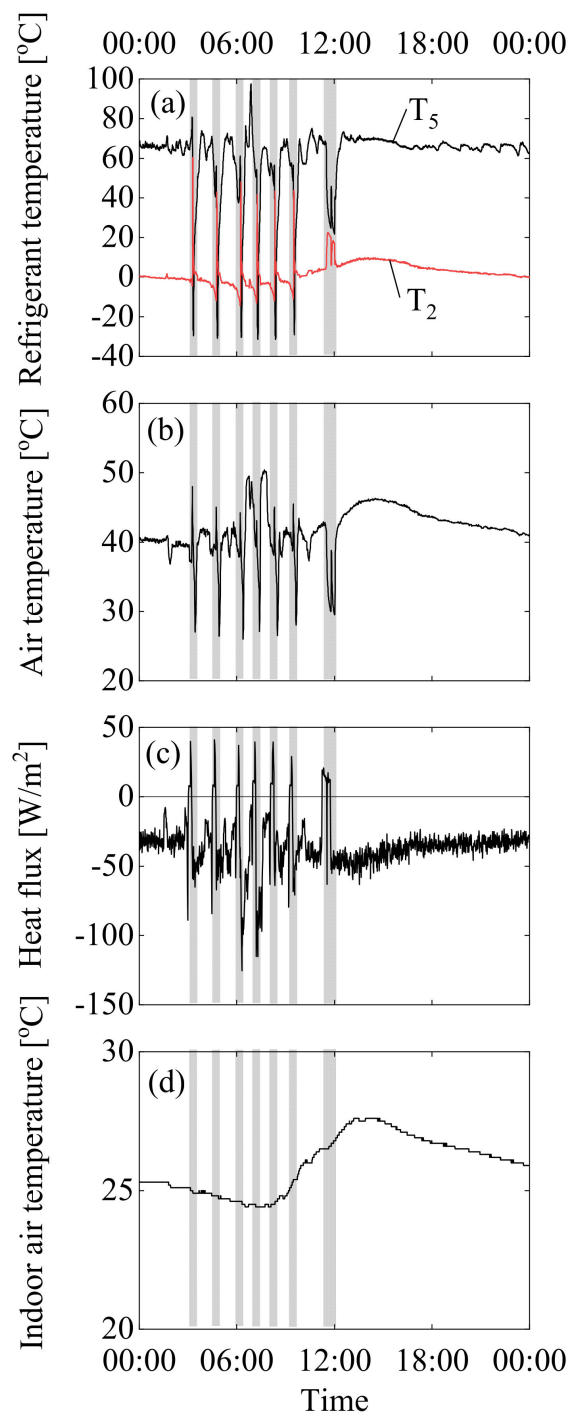

Figure 12. Measurement results (a) Refrigerant temperature, (b) Heating air temperature, (c) Heat flow generated on the foundation slab surface, (d) Indoor air temperature.
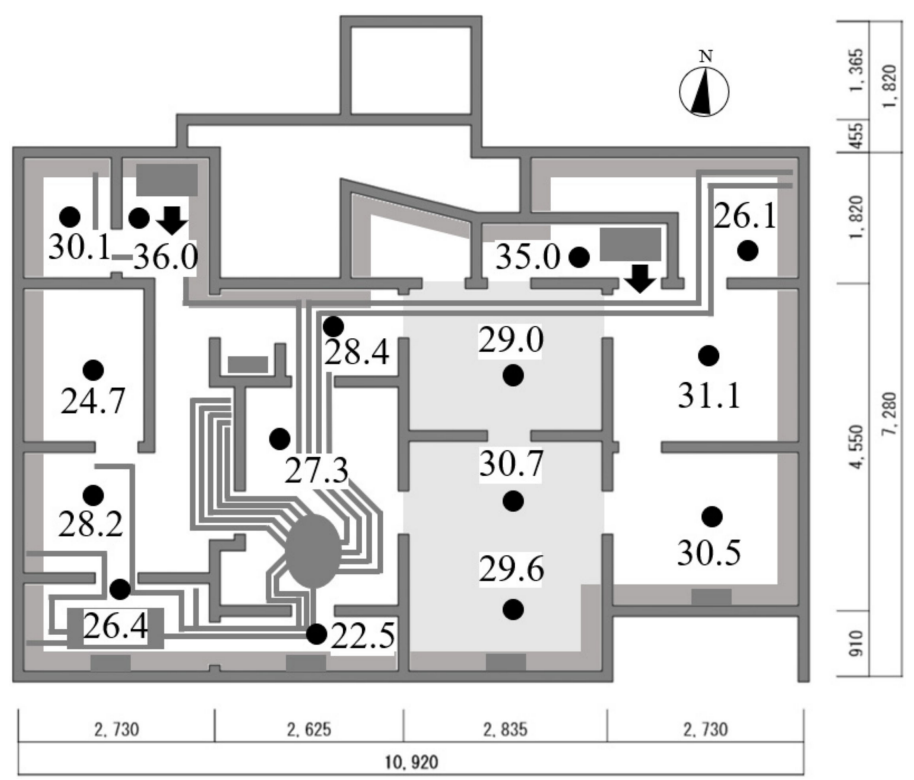

Figure 13. Crawl space air temperature distribution. 


\subsection{Indoor Thermal Environment Survey}

An indoor thermal environment survey and a subjective survey were conducted to evaluate the indoor thermal comfort. The survey results of the indoor thermal environment were provided, followed by those of the subjective survey.

\subsubsection{The Indoor Thermal Environment}

The indoor air temperature during the crawl space heating was measured. Figure 14 shows the outside and indoor air temperatures. The air temperature in the bedroom on the second floor was lower than the air temperature in the living room, kitchen, and bathroom on the first floor. The staircase was the only route for the heating air to move from the first floor to the second floor. The crawl space heating is created by vertical air temperature stratification; therefore, it is necessary to design the space while focusing on the movement path of the heating air to exploit the effect of air temperature stratification.

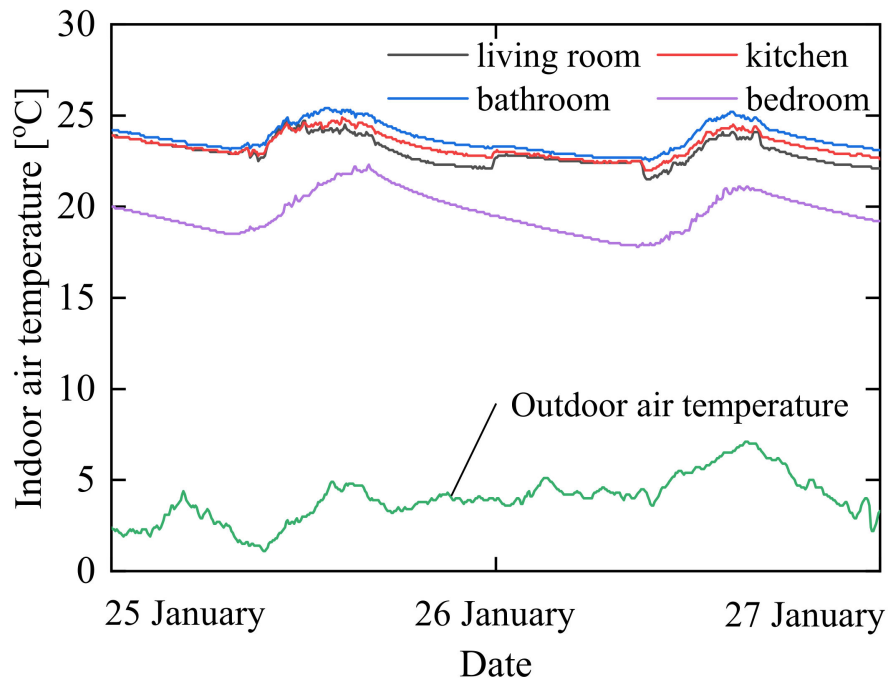

Figure 14. Outside air temperature and indoor air temperature.

The floor surface temperature causes local thermal discomfort. ASHRAE Standard 55 recommends that the percentage dissatisfied resulting from floor surface temperature should be $10 \%$ or less, and the corresponding temperature range is $19-29{ }^{\circ} \mathrm{C}$. Figure 15 shows the floor surface temperatures of the living room, kitchen, and bathroom. The floor surface temperatures in the living room, kitchen, and bathroom varied from 23.1 to $25.5^{\circ} \mathrm{C}$ to 18.4 to $22.3{ }^{\circ} \mathrm{C}$ and $22.1{ }^{\circ} \mathrm{C}$ to $25.0^{\circ} \mathrm{C}$, respectively. Thermal comfort was evaluated based on the dissatisfaction rate caused by the floor surface temperature. The minimum floor surface temperature in the kitchen was lower than the lower limit of the temperature range defined by ISO7730. However, since it is $19^{\circ} \mathrm{C}$ or more at most times, local thermal discomfort is unlikely to occur. However, this result is intended for occupants wearing lightweight indoor shoes. If occupants live indoors wearing only socks, the minimum value of $18.4{ }^{\circ} \mathrm{C}$ in the kitchen may feel cool.

Air temperatures $(0.1 \mathrm{~m})$ above the floor and $1.1 \mathrm{~m}$ above the floor were compared to confirm the vertical air temperature difference. Figure 16 shows the air temperature $(0.1 \mathrm{~m})$ above the floor and $1.1 \mathrm{~m}$ above the floor. ISO 7730 [2] recommends that the vertical air temperature difference between $0.1 \mathrm{~m}$ above the floor and $1.1 \mathrm{~m}$ above the floor should be within $3.0^{\circ} \mathrm{C}$. The maximum and average temperature differences in the living room, kitchen, bathroom, and bedroom were $2.2^{\circ} \mathrm{C}$ and $0.45^{\circ} \mathrm{C}, 7.5^{\circ} \mathrm{C}$ and $5.3^{\circ} \mathrm{C}$, $3.0^{\circ} \mathrm{C}$ and $1.4{ }^{\circ} \mathrm{C}$, and $0.6^{\circ} \mathrm{C}$ and $0.0^{\circ} \mathrm{C}$, respectively. Furthermore, there is a temperature difference of $3.6^{\circ} \mathrm{C}$ at the minimum value in the bathroom. Local thermal discomfort was less likely to occur in the living room, bathroom, and bedroom; however, in the kitchen, it is expected that local thermal discomfort will occur because of the temperature difference. The temperature difference was caused by a decrease in temperature at the feet. The 
temperature drop at the feet was caused by the inflow of cold air from the north entrance. This may be attributed to the decrease in the floor surface temperature of the kitchen, and it can be dealt with by the plan of the house, such as installing a door between the entrance and the kitchen.

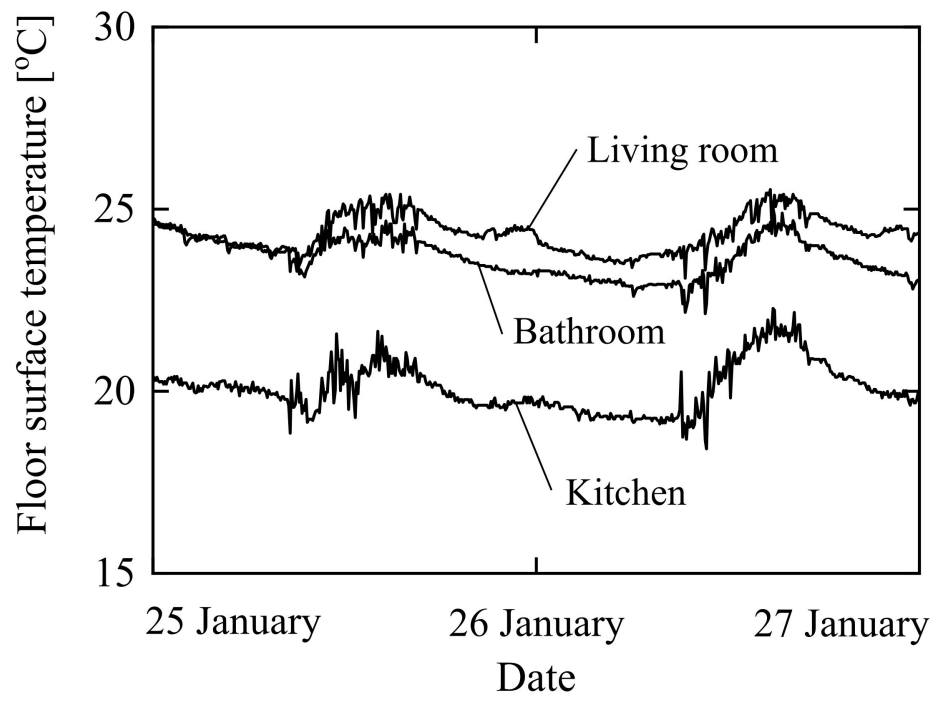

Figure 15. Floor temperature in the living room, kitchen, and bathroom.
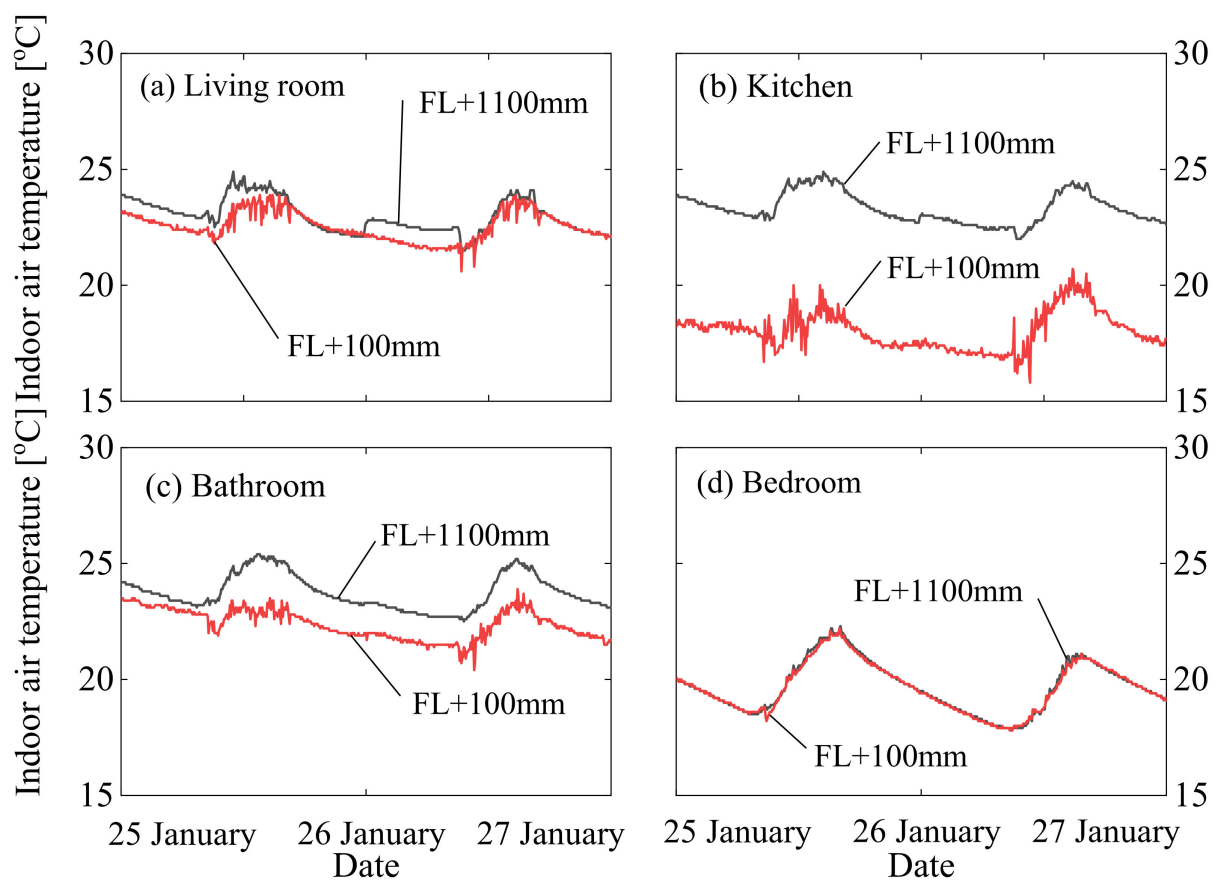

Figure 16. Air temperature of $0.1 \mathrm{~m}$ above the floor and $1.1 \mathrm{~m}$ above the floor in the (a) living room, (b) kitchen, (c) bathroom, and (d) bedroom.

The PMV was calculated to evaluate the indoor thermal environment. Figure 17 shows the time change of the PMV; the standard for the thermal environment defined by ISO7730 [2] is added in this figure. Throughout the measurement period, the thermal environment of the living room was in Category B. The thermal environment of the kitchen met Category $C$ for $71.8 \%$ of the measurement period; it may feel warmer in a kitchen with high activity intensity. Furthermore, the thermal environments in the bathroom and bedroom met Category $C$ for $79.0 \%$ and $53.6 \%$ of the measurement period, respectively. The residents may be more likely to feel cold when waking up because the PMV dropped from midnight to $10 \mathrm{AM}$. 

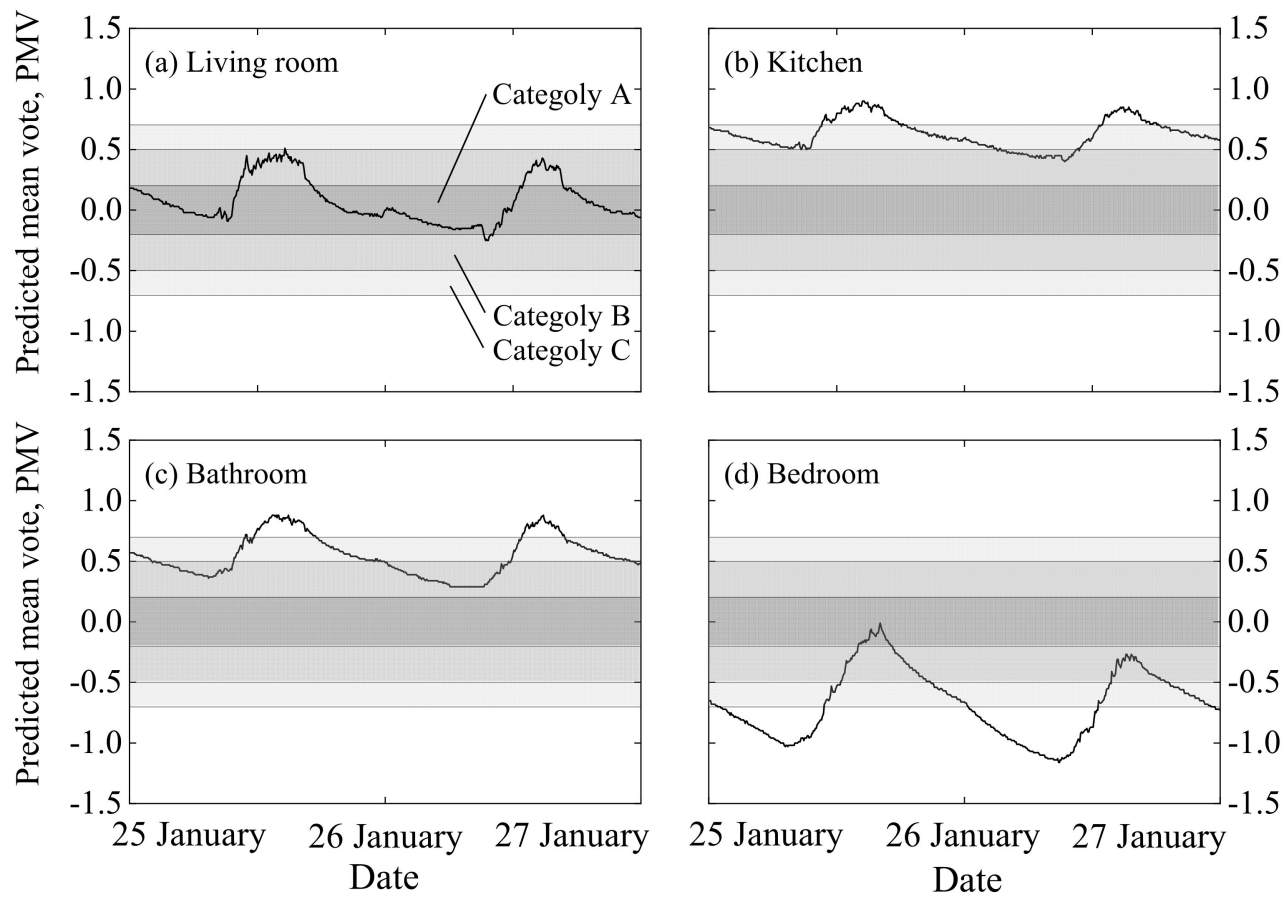

Figure 17. Thermal environment evaluation of (a) living room, (b) kitchen, (c) bathroom, and (d) bedroom based on PMV.

The psychrometric chart in Figure 18 shows the changes in air temperature and absolute humidity caused by air circulation. The plot data include the average value as of 28 January 2020. Because the humidity of the crawl space has not been measured, it was assumed that the absolute humidity of the heating air was uniformly diffused in the crawl space. The heating air was dry, and dry air was supplied to the room. The relative humidity on the first floor was $30.7 \%$, and the relative humidity on the second floor was $43.8 \%$. In Japan, the Ministry of Health, Labor, and Welfare recommends maintaining indoor relative humidity in the range of 40 to $70 \%$. It is necessary to maintain high humidity on the first floor. Humidification is expected because of housework; however, if the dry condition continues, it is necessary to use a humidifier or the like.

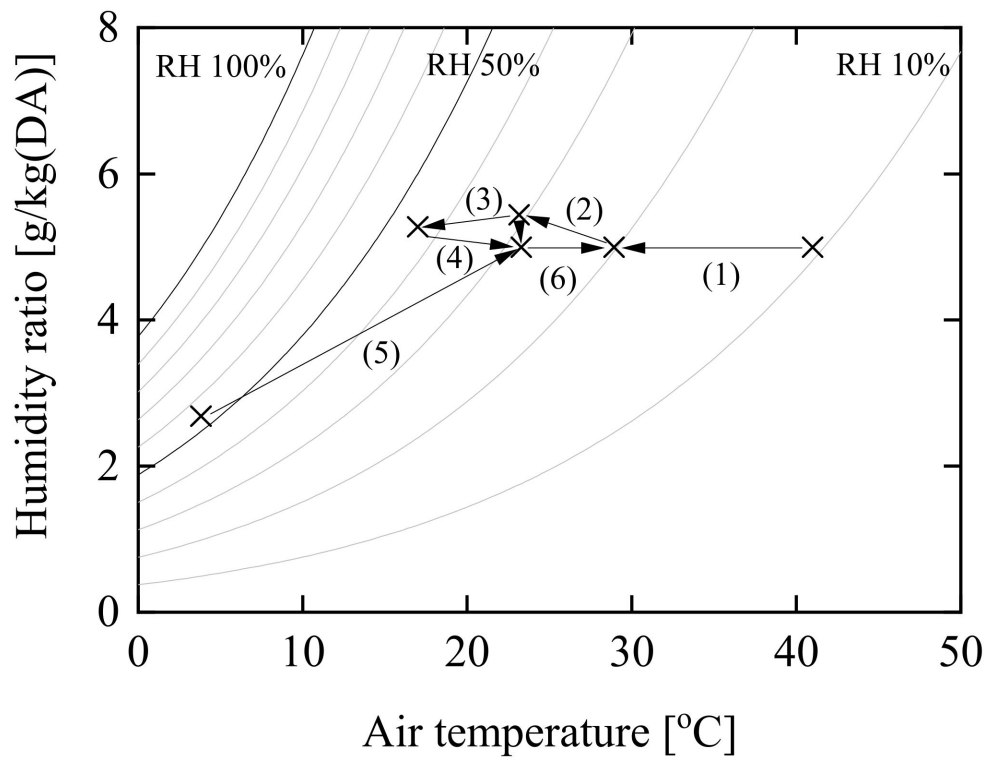

Figure 18. Changes in temperature and humidity properties of indoor air. 


\subsubsection{Subjective Survey}

The survey results were tabulated to evaluate the indoor thermal environment using a subjective vote. A total of 107 valid data were obtained from the survey. Table 10 lists the results of the indoor thermal environment at the time of the subjective survey. The ranges of air temperature 0.1 and $1.1 \mathrm{~m}$ above the floor was $20.8 \sim 23.9{ }^{\circ} \mathrm{C}$ (average value, $20.3^{\circ} \mathrm{C}$ ) and $21.8 \sim 24.9^{\circ} \mathrm{C}$ (average value, $23.6^{\circ} \mathrm{C}$ ), respectively. The range of the indoor operative temperature was $21.9-25.0^{\circ} \mathrm{C}$, and the average value was $23.9^{\circ} \mathrm{C}$.

Table 10. Indoor thermal environment at the time of the subjective survey.

\begin{tabular}{cccccccc}
\hline Measurement Item & Unit & Sample size & Max. & Min. & Mean & S.D. & Median \\
\hline $\begin{array}{c}\text { Air temperature } \\
(0.1 \text { m above the floor })\end{array}$ & ${ }^{\circ} \mathrm{C}$ & 107 & 23.9 & 20.8 & 23.0 & 0.7 & 23.3 \\
\hline $\begin{array}{c}\text { Air temperature } \\
(1.1 \mathrm{~m} \text { above the floor })\end{array}$ & ${ }^{\circ} \mathrm{C}$ & 107 & 24.9 & 21.8 & 23.6 & 0.8 & 23.9 \\
\hline $\begin{array}{c}\text { Air temperature } \\
(1.7 \text { m above the floor })\end{array}$ & ${ }^{\circ} \mathrm{C}$ & 107 & 25.1 & 21.8 & 23.8 & 0.9 & 24.1 \\
\hline Globe temperature & ${ }^{\circ} \mathrm{C}$ & 107 & 25.0 & 21.9 & 23.7 & 0.8 & 24.0 \\
\hline Operative temperature & ${ }^{\circ} \mathrm{C}$ & 107 & 25.0 & 21.9 & 23.7 & 0.8 & 24.0 \\
\hline Relative humidity & $\%$ & 107 & 45.0 & 20.0 & 38.3 & 7.9 & 42.0 \\
\hline Air velocity & $\mathrm{m} / \mathrm{s}$ & 107 & 0.14 & 0.02 & 0.07 & 0.0 & 0.07 \\
\hline Clothing insulation & $\mathrm{clo}$ & 107 & 2.04 & 0.34 & 1.16 & 0.3 & 1.15 \\
\hline
\end{tabular}

The results of the subjective survey were tabulated to understand how the subjects felt the indoor thermal environment. Table 11 lists the results of the survey. Thermal sensations were rated the highest for "warm", followed by "slightly warm". When "warm" is translated into Japanese, it reflects feelings of comfort. Therefore, it had the highest ratings. The affective evaluation observed the highest vote for "comfortable". A majority vote for thermal preference was assigned to "no change". The majority vote for personal acceptance was for "acceptable". Although some subjects voted for "cooler", $88.8 \%$ of the subjects voted for "comfort" and 94.9\% voted for "acceptable". Thus, it can be concluded that many subjects were satisfied with the indoor thermal environment.

Table 11. Result of subjective survey.

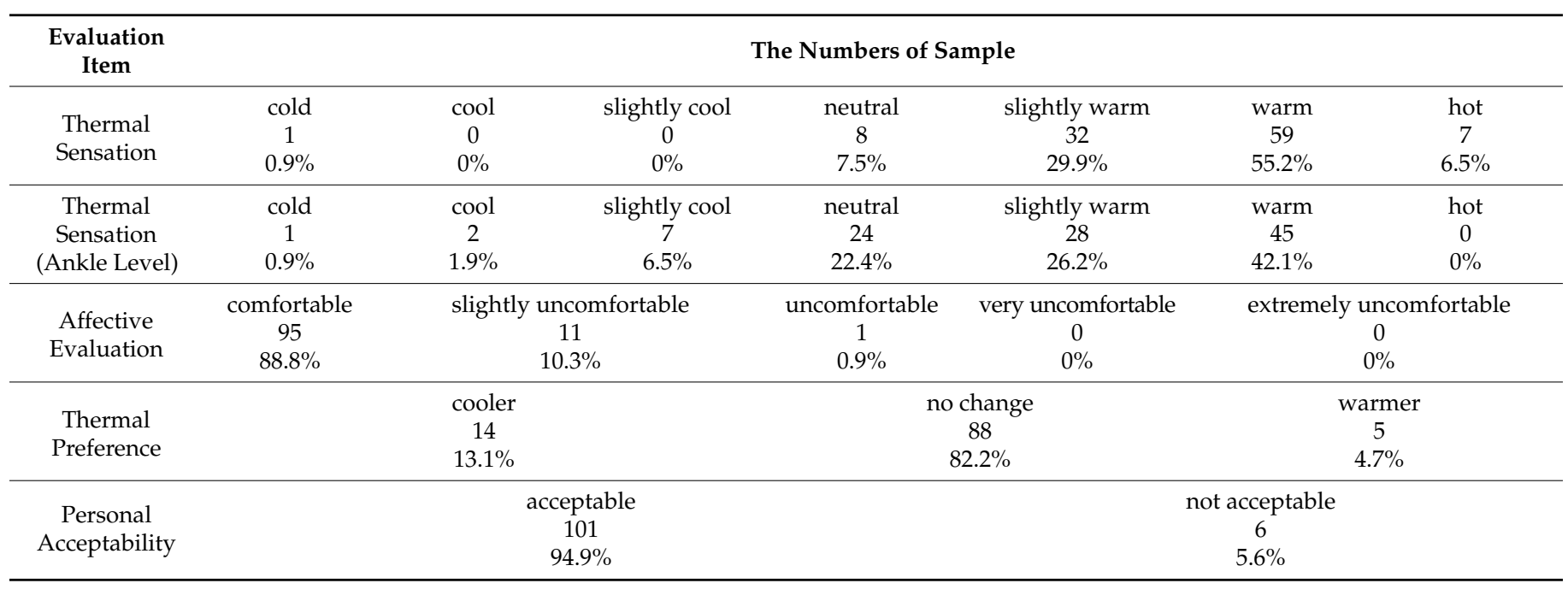


Comparing the thermal sensation vote of the whole body and feet level, the number of votes on the cool side vote of the feet level increased. However, the TSV values of -2 and -3 were $2.8 \%$ of the total. For this reason, a few subjects experienced thermal discomfort.

A scatter plot was drafted to understand the relationship between the indoor operative temperature and TSV. Figure 19 shows the relationship between the indoor operative temperature and the TSV. Because the number of thermal sensation votes was small and the change in the indoor operative temperature during the survey period was also small, it was difficult to analyze this using linear regression. The regression equation was not significant $(p>0.05)$; therefore, the neutral temperature was calculated using the Griffiths method. $t_{n(0.33)}$ was $18.9^{\circ} \mathrm{C}$ and $t_{n(0.5)}$ was $20.5^{\circ} \mathrm{C}$. Based on the comparison of $t_{n(0.5)}$ with the air temperature in the bedroom on the second floor, the air temperature was found to be lower than the neutral temperature at a certain time. Therefore, increasing the air temperature in the bedroom may improve the comfort.

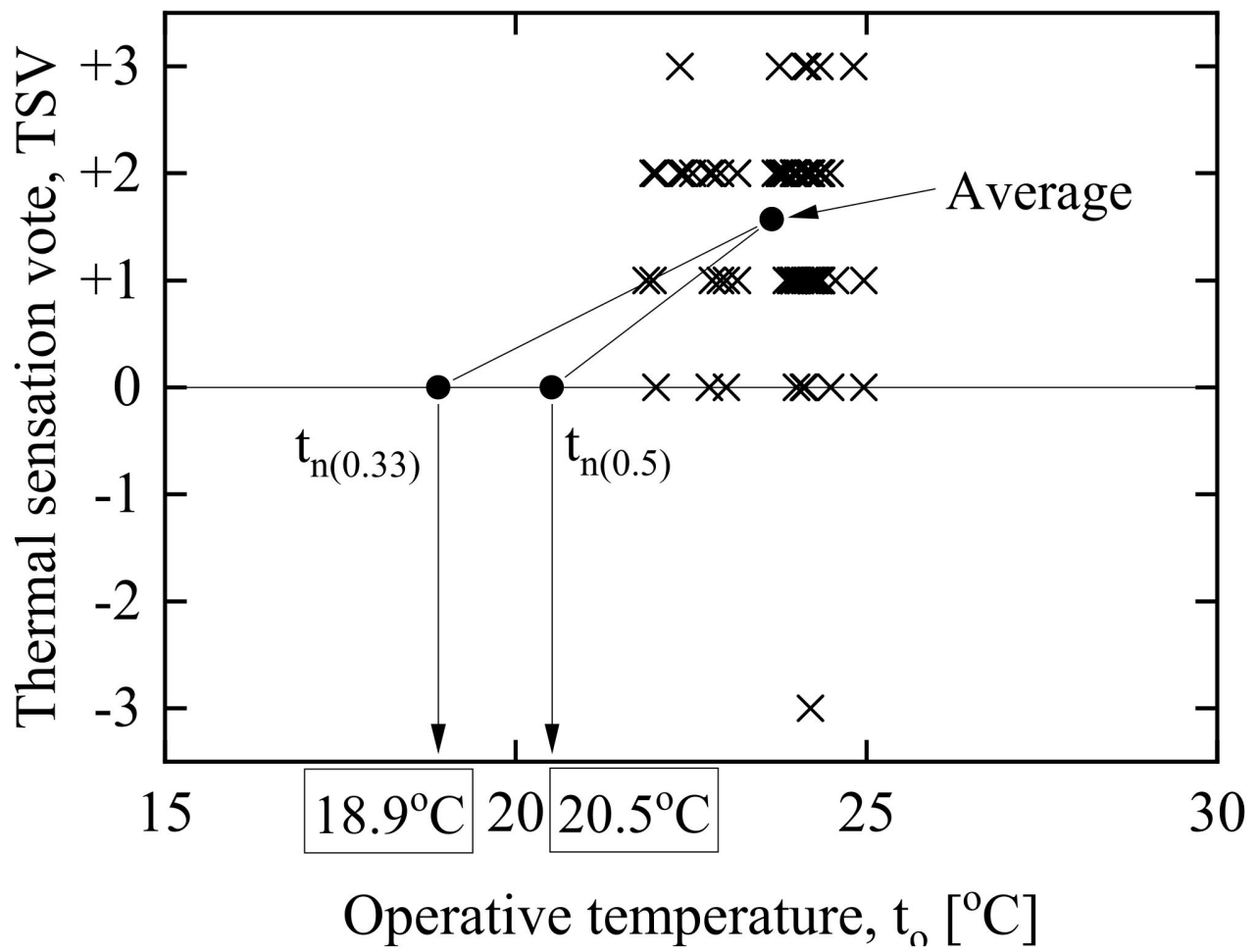

Figure 19. Scatter plot of indoor operative temperature and Thermal sensation vote.

Table 12 summarizes previous studies conducted in housing in winter to compare the results of this study with their results [48-62]. The types of housing include detached houses, apartments, and elderly housing with care. This study was compared with a study that employed a coefficient of 0.33 (Rijal et al. [52], Jiao et al. [56], Gautam et al. [58]). Compared with these previous studies, the neutral temperature of this study tended to be higher. Compared with the study by Tobita et al., There was a large difference in the neutral temperature in the same country. Since the target house of this study was an exhibition house, the subjects did not stay for a long time. After entering the warm house from the cold outside, a subjective report survey was conducted about 30 minutes later. Thermal overshoots can occur. Therefore, it is probable that the number of declarations of "slightly warm" and "warm" increased, and the neutral temperature became higher. 
Table 12. Previous studies conducted in housing and facilities for the elderly in winter.

\begin{tabular}{|c|c|c|c|c|c|c|c|}
\hline Reference & Country/Location & Climate & Sample & Age & Operation & Equation & $t_{n}$ \\
\hline $\begin{array}{c}\text { Oseland_1994 } \\
{[48]}\end{array}$ & (Database of UK) & - & - & $20-77$ & $\mathrm{AC}$ & $T S V=0.24 t_{o}-0.15$ & 17.0 \\
\hline Wang_2003 & Harbin, China & very cold and dry & 120 & $14-80$ & - & $T S V=0.302 t_{0}-6.506$ & 21. \\
\hline Wang_2006 & Harbin, China & very cold and dry & 59 & $14-80$ & - & $T S V=0.199 \mathrm{t}_{\mathrm{o}}-4.158$ & $20.9^{1}$ \\
\hline $\begin{array}{c}\text { Tobita et al._2007 } \\
\text { [51] }\end{array}$ & Kansai, Japan & $\mathrm{Cfa}$ & 396 & - & Mixed & $\begin{array}{c}\text { TSV }=0.12 \mathrm{ET} *+2.81 \\
\text { TSV }=0.13 \mathrm{t}_{\mathrm{g}}+2.70 \\
\text { TSV }=0.14 \mathrm{t}_{\mathrm{o}}+2.47 \\
\text { TSV }=0.14 \mathrm{ET} *+2.45\end{array}$ & $\begin{array}{c}9.9^{2} \\
9.9^{3} \\
10.9^{3} \\
10.9^{3}\end{array}$ \\
\hline \multirow[t]{6}{*}{$\begin{array}{l}\text { Rijal et al._2010 } \\
\text { [52] }\end{array}$} & Banke, Nepal & sub-tropical & 264 & - & NV & (Griffiths 0.33) & $\begin{array}{l}16.2 \\
18.3\end{array}$ \\
\hline & Bhaktapur, Nepal & temperate & 616 & - & NV & (Griffiths 0.33) & $\begin{array}{l}15.2 \\
20.9\end{array}$ \\
\hline & Dhading, Nepal & temperate & 352 & - & NV & (Griffiths 0.33) & $\begin{array}{l}24.2 \\
26.8\end{array}$ \\
\hline & Kaski, Nepal & temperate & 176 & - & NV & (Griffiths 0.33) & $\begin{array}{l}18.0 \\
18.2\end{array}$ \\
\hline & Solukhumbu, Nepal & cold climate & 528 & - & NV & (Griffiths 0.33) & $\begin{array}{l}13.4 \\
14.7\end{array}$ \\
\hline & all & - & 1936 & $17-60$ & NV & $\begin{aligned} T S V= & 0.0509 \mathrm{t}_{\mathrm{g}}-1.2373 \\
& (\text { Griffith } 0.33)\end{aligned}$ & $\begin{array}{l}24.3 \\
17.3\end{array}$ \\
\hline $\begin{array}{l}\text { Wang et al._2010 } \\
\text { [53] }\end{array}$ & Harbin, China & very cold and dry & 432 & $20-60$ & NV & - & 21.5 \\
\hline \multirow{2}{*}{$\begin{array}{l}\text { Wang et al._2011 } \\
\text { [54] }\end{array}$} & Harbin, China & very cold and dry & 174 & $20-60$ & no heating & $T S V=0.0915 \mathrm{t}_{\mathrm{a}}-2.2977$ & 25.1 \\
\hline & & & & & heating & $T S V=0.1074 \mathrm{t}_{\mathrm{a}}-2.189$ & 20.4 \\
\hline $\begin{array}{c}\text { Liu et al._2017 } \\
\text { [55] }\end{array}$ & China & $\mathrm{HSCW}$ & 2652 & $20-60$ & NV & $T S V=0.066 \mathrm{t}_{\mathrm{o}}-1.39$ & 21.0 \\
\hline $\begin{array}{c}\text { Jiao et al._2017 } \\
\text { [56] }\end{array}$ & Shaghai, China & subtropical humid monsoon & 342 & over 70 & NV & $\begin{array}{c}T S V=0.079 t_{\mathrm{o}}-1.310 \\
\text { (Griffiths 0.5) } \\
\text { (Griffiths 0.33) } \\
\text { (Griffiths 0.25) }\end{array}$ & $\begin{array}{l}16.6 \\
14.2 \\
14.0 \\
13.7\end{array}$ \\
\hline $\begin{array}{c}\text { Wang et al._2018 } \\
\text { [57] }\end{array}$ & Shaghai, China & subtropical humid monsoon & 342 & $70-98$ & NV & $T S V=0.078 t_{0}-1.306$ & 16.7 \\
\hline $\begin{array}{c}\text { Gautam et al._2019 } \\
\text { [58] }\end{array}$ & Mustang, Nepal & cold & 60 & $14-86$ & - & $\begin{array}{l}\text { (Griffiths 0.5) } \\
\text { (Griffiths 0.33) }\end{array}$ & $\begin{array}{l}13.8^{4} \\
14.7^{5}\end{array}$ \\
\hline
\end{tabular}


Table 12. Cont.

\begin{tabular}{|c|c|c|c|c|c|c|c|}
\hline Reference & Country/Location & Climate & Sample & Age & Operation & Equation & $t_{n}$ \\
\hline \multirow{7}{*}{$\begin{array}{c}\text { Xiong et al._2019 } \\
\text { [59] } \\
\text { Jiao et al._2020 } \\
\text { [60] }\end{array}$} & \multirow[t]{2}{*}{ Kavrepalanchok, Nepal } & \multirow[t]{2}{*}{ temperate } & \multirow[t]{2}{*}{85} & \multirow[t]{2}{*}{$14-86$} & \multirow[t]{2}{*}{-} & (Griffiths 0.5) & $17.9^{4}$ \\
\hline & & & & & & (Griffiths 0.33) & $18.5^{5}$ \\
\hline & \multirow[t]{2}{*}{ Sarlahi, Nepal } & \multirow[t]{2}{*}{ sub-tropical } & \multirow[t]{2}{*}{130} & \multirow[t]{2}{*}{$14-86$} & \multirow[t]{2}{*}{-} & (Griffiths 0.5) & $23.1^{4}$ \\
\hline & & & & & & (Griffiths 0.33) & $22.8^{5}$ \\
\hline & Wuhan, China & HSCW & 212 & $14-74$ & Mixed & $T S V=0.10 \mathrm{t}_{\text {in }}-1.94$ & $19.4^{6}$ \\
\hline & Luotuoao, China & HSCW & 631 & $14-74$ & Mixed & $T S V=0.09 \mathrm{t}_{\mathrm{in}}-1.45$ & $16.1^{6}$ \\
\hline & Shanghai, China & subtropical humid monsoon & 342 & over 70 & $\mathrm{NV}$ & $T S V=0.076 \mathrm{t}_{\mathrm{o}}-1.273$ & 16.8 \\
\hline $\begin{array}{c}\text { Jin et al._2020 } \\
\text { [61] }\end{array}$ & Edinburgh, Scotland, UK & - & - & $83-94$ & $\mathrm{AC}$ & - & 22.7 \\
\hline \multirow{8}{*}{$\begin{array}{l}\text { Shao and Jin_2020 } \\
\text { [62] }\end{array}$} & Harbin, China & severely cold & 100 & - & $\mathrm{AC}$ & $T S V=0.2203 t_{o}-3.7013$ & 16.8 \\
\hline & Changchun, China & severely cold & 100 & - & $\mathrm{AC}$ & $T S V=0.2467 \mathrm{t}_{\mathrm{o}}-4.0579$ & 16.4 \\
\hline & Shenyang, China & severely cold & 100 & - & $\mathrm{AC}$ & $T S V=0.2322 \mathrm{t}_{\mathrm{o}}-3.715$ & 16.0 \\
\hline & & & - & below 44 & $\mathrm{AC}$ & $T S V=0.197 \mathrm{t}_{\mathrm{o}}-3.299$ & 16.8 \\
\hline & & & - & 44-59 & $\mathrm{AC}$ & $T S V=0.206 t_{0}-3.424$ & 16.6 \\
\hline & & & - & over 60 & $\mathrm{AC}$ & $T S V=0.213 \mathrm{t}_{\mathrm{o}}-3.511$ & 16.5 \\
\hline & & & - & & $\mathrm{AC}$ & $T S V=0.205 t_{0}-3.350$ & $16.3^{1}$ \\
\hline & & \multirow{3}{*}{$\mathrm{Cfa}$} & - & \multirow{3}{*}{$10-60$} & $\mathrm{AC}$ & $T S V=0.217 \mathrm{t}_{\mathrm{o}}-3.639$ & $16.8^{2}$ \\
\hline \multirow[t]{2}{*}{ This study_2020 } & \multirow{2}{*}{ Saku, Japan } & & \multirow[t]{2}{*}{107} & & \multirow[t]{2}{*}{$\mathrm{AC}$} & (Griffiths 0.5) & 20.5 \\
\hline & & & & & & (Griffiths 0.33) & 18.9 \\
\hline
\end{tabular}

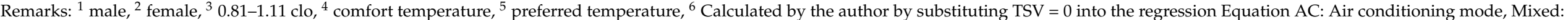
Mixed mode, NV: Naturally ventilated mode. ET ${ }^{*}=$ New effective temperature. 


\subsection{Heat Loss from the Crawl Space}

\subsubsection{Measurement of Heat Loss}

The heat transfer in the crawl space was investigated on 2 February 2020. Figure 20 shows the heat transfer from the crawl space; the ratio of heat transfer to the heat supply is also shown. A part of the heat supply was probably consumed by the introduction of outside air via the ventilation system. Furthermore, it is difficult to accurately measure all heat flux. Therefore, the heat transfer generated on the foundation slab surface may be larger than the measured value. The heat transfer generated on the foundation slab corresponds to the total of $20 \%$ of the heat supply. It is necessary to consider insulation placement on the foundation to reduce the heat transfer generated on the foundation slab.

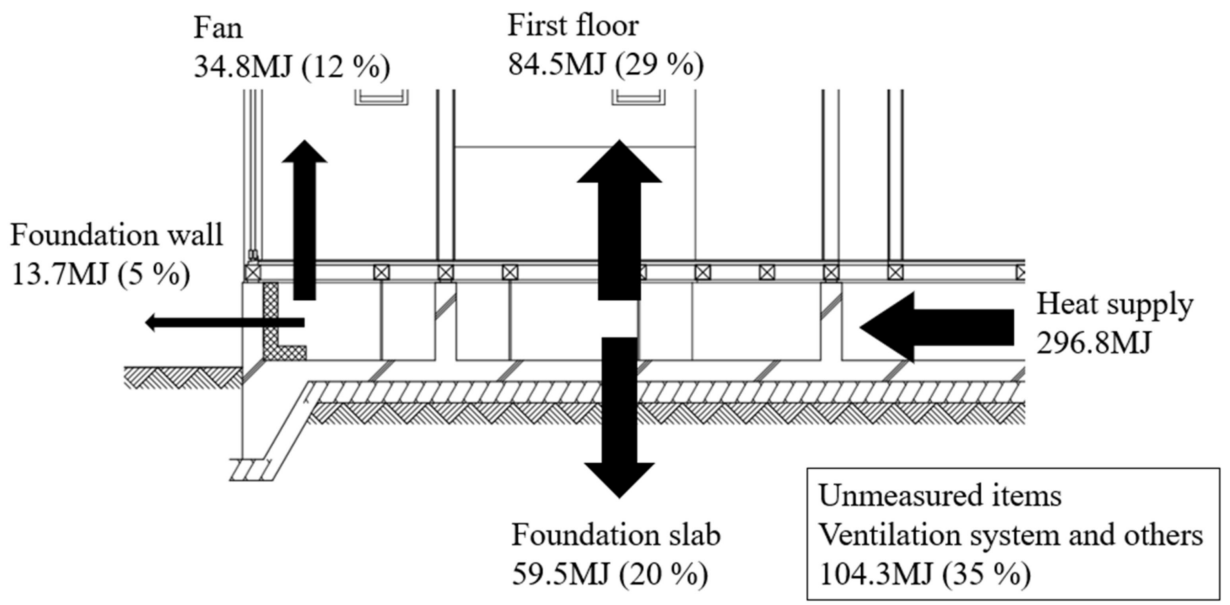

Figure 20. Heat transfer of crawl space.

The heat flux was compared at each measurement point, as shown in Figure 21. It was necessary to place the insulation because the heat flux generated on the foundation slab surface was large near the air conditioner. The heat flux generated on the insulated foundation slab surface was small compared to the other measurement points. Placing insulation on the foundation slab or foundation wall is effective for decreasing heat loss. However, in the measurement, the heat flux of outer peripheral portion cannot be accurately evaluated. Therefore, the analysis is used to supplement the evaluation of the heat flux of the foundation slab and to propose the insulation length.

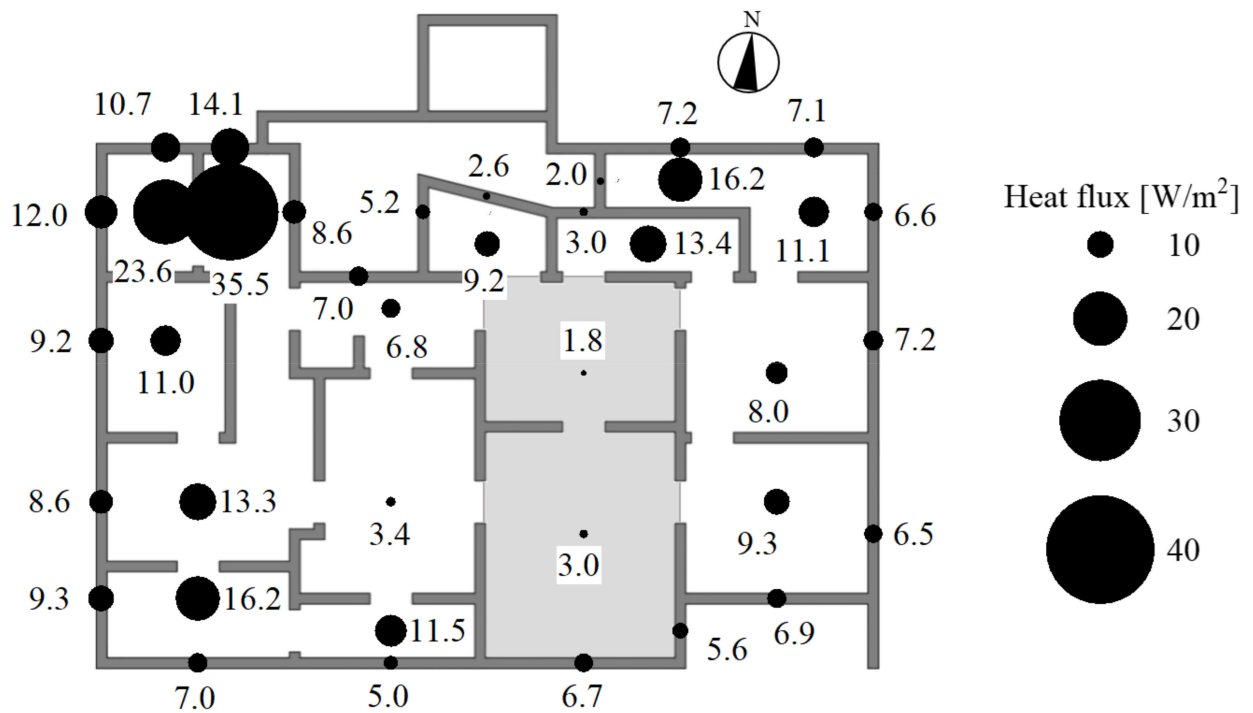

Figure 21. Comparison of heat flux generated in foundation slabs and foundation walls. 


\subsubsection{Calculating Heat Loss by Analysis}

An analysis was conducted to understand the differences in the insulation placement. Figure 22 shows an example of the distribution of the ground temperature and heat flux for each insulation placement. In the original model, a temperature gradient was generated near the foundation wall, and the heat was easily transferred. Therefore, the heat flux generated on the foundation slab surface near the foundation wall increases. It is necessary to employ measures to reduce the maximum heat flux to suppress the heat loss. In Case $1(\mathrm{~L}=1820 \mathrm{~mm})$, the temperature lines at $10{ }^{\circ} \mathrm{C}$ and $15{ }^{\circ} \mathrm{C}$ were distributed under the foundation slab. It was difficult for the heat to escape because the temperature gradient was smaller than that of the original model. Therefore, the maximum heat flux decreased. In Case $2\left(\mathrm{~L}_{1}=1820 \mathrm{~mm}\right)$, the ground temperature distribution was similar to that of the original model, even when the insulation was placed. The foundation concrete became a thermal bridge, and a temperature gradient was generated, which made it easy for the heat to escape; therefore, the maximum heat flux did not decrease. In Case $3\left(\mathrm{~L}_{2}=100 \mathrm{~mm}\right)$, the ground temperature under the foundation slab was $20-30{ }^{\circ} \mathrm{C}$ because the outside cold air was blocked outside the foundation wall. The heat flux was small because the temperature gradient under the foundation slab was small.
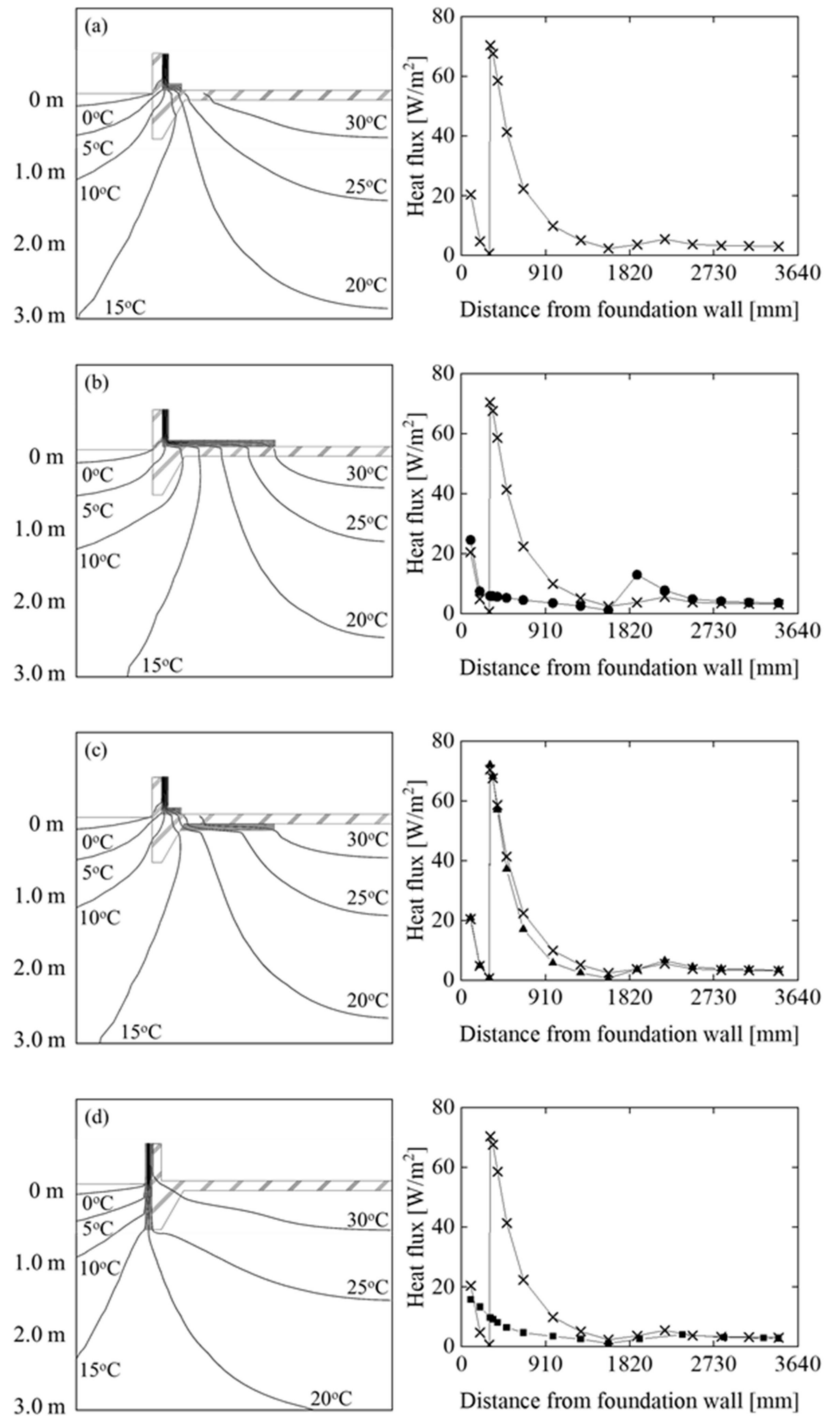

Figure 22. The example of the distribution of ground temperature and heat flux in each insulation placement. (a) Original $(\mathrm{L}=1820 \mathrm{~mm})$, (b) Case $1(\mathrm{~L}=1820 \mathrm{~mm})$, (c) Case $2(\mathrm{~L}=1820 \mathrm{~mm})$, (d) Case 3 ( $\mathrm{L}=100 \mathrm{~mm})$. 
The heat flux generated on the foundation slab surface was analyzed for each insulation placement. Figure 23 shows the heat flux distribution generated on the surface of the foundation slab when the insulation length is changed. Furthermore, the figure shows the heat flux distribution on February 1, when the maximum surface temperature of the foundation slab was set. In Case 1, the maximum heat flux generated on the foundation slab surface was reduced by extending the insulation; however, the decrease in the maximum heat flux became smaller as the heat-insulating material was extended. In Case 2, the heat flux distribution generated on the foundation slab surface showed the same heat flux distribution as the original model. Because the thermal bridge occurred in the foundation concrete, the change in the maximum heat flux caused by the extension of the insulation was small. In Case 3, the heat flux was larger as it was closer to the foundation wall; the maximum value changed in the range of 15.6 to $16.3 \mathrm{~W} / \mathrm{m}^{2}$. There was no change in the heat flux distribution generated on the foundation slab surface by extending the skirt insulation.

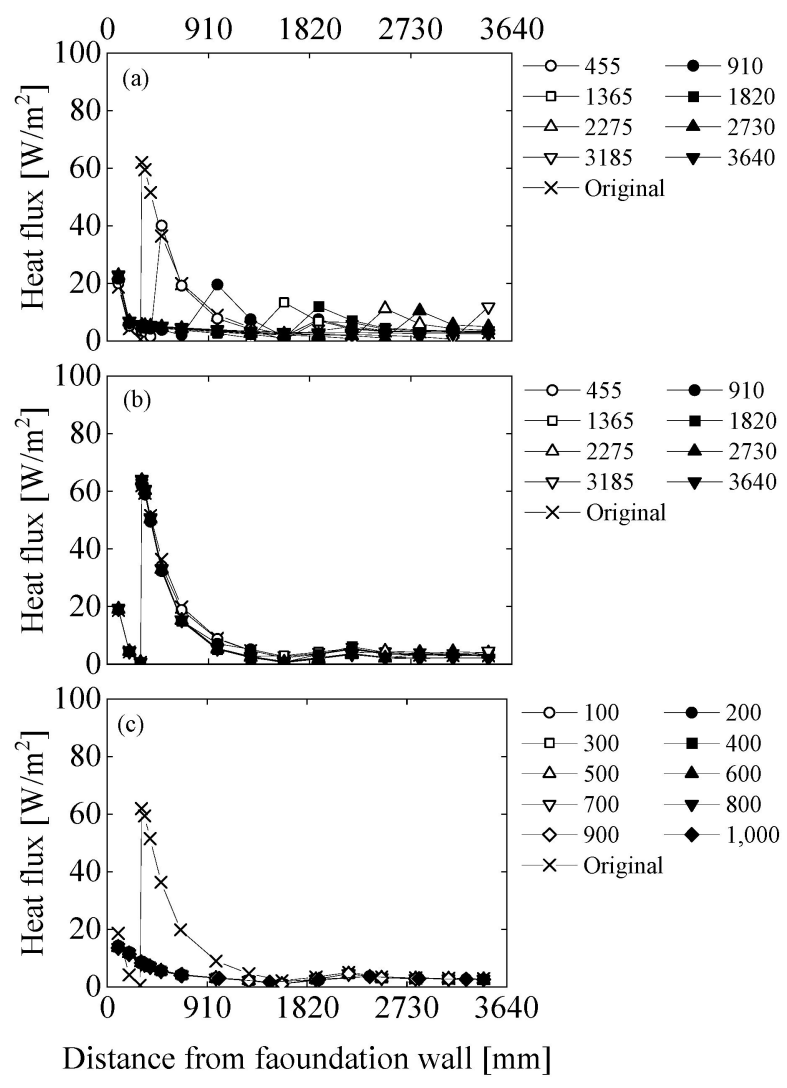

Figure 23. Heat flux distribution on the foundation slab surface in each insulation placement. (a) Case 1, (b) Case 2, (c) Case 3 .

The average heat loss during the heating period was calculated. The heating period was assumed to be 121 days, from 1 December to 31 March. Figure 24 shows the relationship between the insulation length and heat loss; the result is the heat loss per $9.9 \mathrm{~m}^{2}$ in the analysis range. The heat loss in Case 1 was the smallest at $\mathrm{L}=3640 \mathrm{~mm}$, and the heat loss was $369.0 \mathrm{MJ}$. It was $578.3 \mathrm{MJ}$ less than that of the original model. The longer the insulation, the smaller is the heat loss. However, the longer the insulation length, the smaller the effect of decreasing the heat loss caused by the extension of the insulation. In Case 2, the heat loss was the smallest at $\mathrm{L}_{1}=3185 \mathrm{~mm}$, which was $749.9 \mathrm{MJ}$. However, it was $770.7 \mathrm{MJ}$ at $\mathrm{L}_{1}=910 \mathrm{~mm}$. Comparing $\mathrm{L}_{1}=910 \mathrm{~mm}$ with $\mathrm{L}_{1}=3185 \mathrm{~mm}$, the heat loss decreased by only $2.8 \%$. Therefore, it is not expected that the heat loss will be reduced by extending the insulation. In Case 3, at $\mathrm{L}_{2}=100-1000 \mathrm{~mm}$, the minimum heat loss was $408.4 \mathrm{MJ}$ and the maximum was $423.6 \mathrm{MJ}$. It cannot be expected that skirt insulation will decrease heat loss. The results indicate that the appropriate insulation length in Case 2 is $L_{1}=910 \mathrm{~mm}$, 
and in Case 3, it is $\mathrm{L}_{2}=100 \mathrm{~mm}$. However, in Case 1, it was not possible to determine the appropriate insulation length only from the viewpoint of heat loss. Therefore, it is necessary to consider the insulation length. The insulation length for Case 1 was proposed based on electricity and insulation costs.
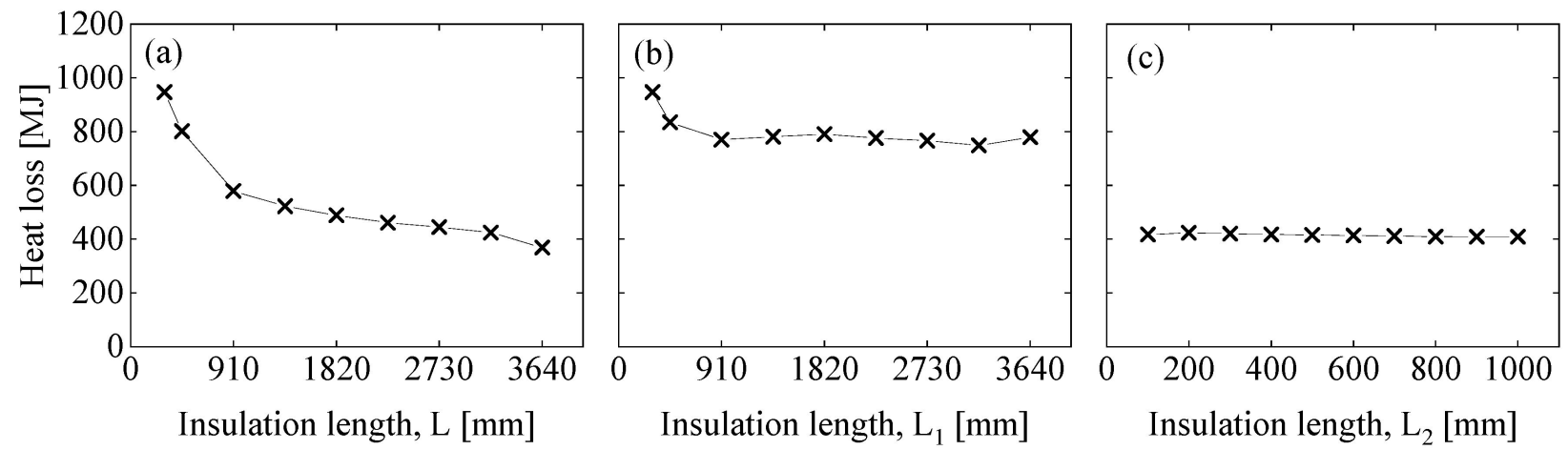

Figure 24. Heat loss on the foundation slab surface in each insulation placement. (a) Case 1, (b) Case 2, (c) Case 3.

The electric, insulation, and total costs were calculated for a detached house to examine the appropriate insulation length in Case 1. The total cost is the sum of the electric and insulation costs. The length that minimizes the total cost is the appropriate insulation length. First, it was converted into power consumption, corresponding to the heat loss. Subsequently, the power consumption was divided by the COP of the air conditioner to calculate the power consumption expected to be consumed. Finally, the electric costs were calculated by multiplying the power consumption by the standard unit price of the electricity rate.

Figure 25 shows the relationship between the insulation length and the annual cost for a detached house. Annual costs were compared assuming 20, 40, and 60 years of residence. In this study, heat loss other than that during the heating period was not considered, and only heating was assumed. Because the heating period was fixed, the annual electric costs were constant regardless of the residence years. The annual insulation costs varied depending on the residence years, and the longer the residence years, the lower the insulation cost. The appropriate insulation length based on the annual total cost calculation was $455 \mathrm{~mm}$ for 20 residence years and $910 \mathrm{~mm}$ for 40 and 60 residence years. Considering the longevity of wooden buildings, the insulation length placed on the foundation slab was appropriate at $\mathrm{L}=910 \mathrm{~mm}$. The insulation length in the target house of this study was $300 \mathrm{~mm}$; however, the heat loss could be reduced by extending the heat-insulating material. Furthermore, setting the insulation length to $910 \mathrm{~mm}$ was found to be cost-effective.
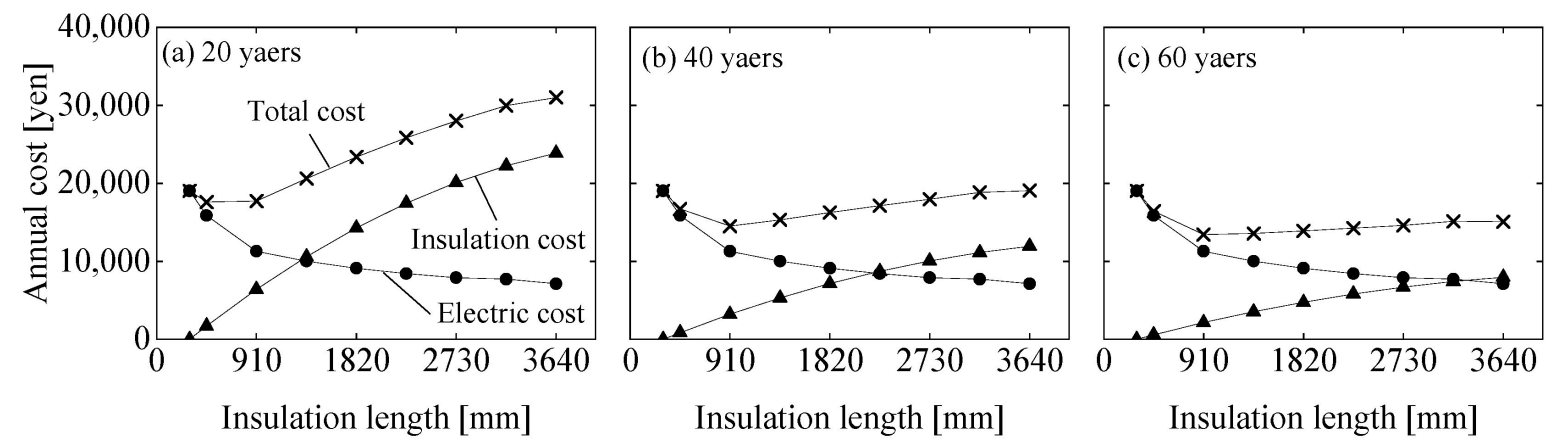

Figure 25. Annual cost of insulation cost and electric cost versus insulation length. (a) 20 residence years, (b) 40 residence years, (c) 60 residence years.

In Japan's energy-saving housing design [3], it is not necessary to make the foundation slab a heat insulating structure. However, due to the influence of external cold air, the temperature under the foundation slab decreased. The insulation of foundation slabs 
requires the elimination of thermal bridges and the reduction of the maximum heat flux generated in foundation slabs. This study showed that heat loss was suppressed by the placement and extension of insulation. This result will help the design when introducing the crawl space heating not only in Japanese houses but also in other region houses.

\section{Conclusions}

This report showed the comfort of the indoor thermal environment, the operating performance of the room air conditioner, and the appropriate length of the insulation of the foundation slab. This result aids in the design of the crawl space heating in detached homes. Some simple results, limitations, and future challenges are shown as follows:

When operating the air heat source heat pump in winter, there was a risk that the operating performance would deteriorate due to frost formation on the evaporator. However, from the research results, the heat pump operated efficiently. According to the $\mathrm{p}-\mathrm{h}$ diagram, it was shown that the heating operation of the heat pump was performed normally. Therefore, it is possible to select air heat source heat pump as the heating equipment in cold region. In this study, the installation position of the room air conditioner was not examined. Since it is important to distribute the heating air into the crawl space, there is room to consider the installation position of the air conditioner.

In the indoor thermal environment survey, there was almost no local thermal discomfort, and the subjects were satisfied with the indoor thermal environment. However, the subjective survey was conducted in a stable temperature environment, so the change in the thermal sensation with respect to the temperature change could not be confirmed. In addition, the number of subjects was small, and it was difficult to discuss individual differences in the thermal sensations. Therefore, by expanding the temperature range in which the subjective survey is conducted and increasing the number of thermal sensation vote, comfort will be evaluated more clearly.

Three types of insulation placements were set for the foundation slab, and an appropriate length was presented from the viewpoint of suppressing heat loss. However, Latent heat and moisture transfer were not considered in the comparison of heat loss by two-dimensional analysis. Freezing of the ground and groundwater levels can affect heat transfer and should be reproduced in the next study.

Author Contributions: Conceptualization, H.I., Y.O. and T.N.; methodology, H.I. and T.N.; software, H.I.; validation, H.I. and T.N.; formal analysis, H.I.; investigation, H.I. and Y.O.; resources, Y.O. and T.N.; data curation, H.I.; writing—original draft preparation, H.I.; writing-review and editing, H.I.; visualization, H.I.; supervision, T.N.; project administration, H.I., Y.O. and T.N. All authors have read and agreed to the published version of the manuscript.

Funding: This research did not receive any specific grant from funding agencies in the public, commercial, or not-for-profit sectors.

Institutional Review Board Statement: Questionnaire survey items were examined based on the Helsinki Convention. Maximum consideration was given to ensuring the anonymity of the subjects and not forcing them to respond.

Informed Consent Statement: Informed consent was obtained from all subjects involved in the study.

Data Availability Statement: Data sharing not applicable.

Conflicts of Interest: The authors declare no conflict of interest.

\section{References}

1. ANSI/ASHRAE Standard. 55-2017 Thermal Environmental Conditions for Human Occupancy; American Society of Heating, Refrigerating and Air Conditioning Engineers, Inc.: Atlanta, GA, USA, 2017.

2. ISO 7730. Ergonomics of the Thermal Environment-Analytical Determination and Interpretation of Thermal Comfort Using Calculation of the PMV and PPD Indices and Local Thermal Comfort Criteria; International Organization for Standardization: Geneva, Switzerland, 2005.

3. Housing Energy Saving Technology Training Text Design/Construction; Reiwa 2nd Revised Building Energy Saving Law Briefing Session and Housing Energy Saving Technology Class (Online Course). Available online: https://www.shoene.org/d_book/ (accessed on 20 October 2021). (In Japanese) 
4. Hwang, Y.-J.; Jeong, J.-W. Energy Saving Potential of Radiant Floor Heating Assisted by an Air Source Heat Pump in Residential Buildings. Energies 2021, 14, 1321. [CrossRef]

5. Kropas, T.; Streckienè, G.; Bielskus, J. Experimental Investigation of Frost Formation Influence on an Air Source Heat Pump Evaporator. Energies 2021, 14, 5737. [CrossRef]

6. Asama, H.; Akabayashi, S.-I.; Sakaguchi, J. Study on the performance of household air-conditioner in the practical use: Results of COP on an air-conditioner at 13 detached houses. J. Environ. Eng. (Trans. AIJ) 2007, 72, 35-40. [CrossRef]

7. Wang, W.; Feng, Y.; Zhu, J.; Li, L.; Guo, Q.; Lu, W. Performances of air source heat pump system for a kind of mal-defrost phenomenon appearing in moderate climate conditions. Appl. Energy 2013, 112, 1138-1145. [CrossRef]

8. Guo, X.-M.; Chen, Y.-G.; Wang, W.-H.; Chen, C.-Z. Experimental study on frost growth and dynamic performance of air source heat pump system. Appl. Therm. Eng. 2008, 28, 2267-2278. [CrossRef]

9. Bauman, F.S. Underfloor Air Distribution (UFAD) Design Guide; American Society of Heating, Refrigerating and Air-Conditioning Engineering: Atlanta, GA, USA, 2003.

10. Bauman, F.; Webster, T. Outlook for underfloor air distribution. ASHRAE J. 2001, 43, 18-27.

11. Fukao, H.; Ichihara, M.; Oguro, M.; Tanabe, S. Comparison of Underfloor vs. Overhead Air Distribution Systems in an Office Building. ASHRAE Trans. 2002, 108, 64-76.

12. Sekhar, S.; Ching, C. Indoor air quality and thermal comfort studies of an under-floor air-conditioning system in the tropics. Energy Build. 2002, 34, 431-444. [CrossRef]

13. Bos, M.A.; Love, J.A. A field study of thermal comfort with underfloor air distribution. Build. Environ. 2013, 69, 233-240. [CrossRef]

14. Faulkner, D.; Fisk, W.; Sullivan, D. Indoor airflow and pollutant removal in a room with floor-based task ventilation: Results of additional experiments. Build. Environ. 1995, 30, 323-332. [CrossRef]

15. Webster, T.; Bauman, F.; Reese, J. Underfloor air distribution: Thermal stratification. ASHRAE J. 2002, 44, 28-36.

16. Giles, J.R. Energy Comparison of Under Floor Air Distribution Heating Ventilation and Air Conditioning Systems in Office Buildings; Iowa State University: Ames, IA, USA, 2008. [CrossRef]

17. Inatomi, T.A.; Abe, V.; Leite, B.C. Energy consumption of underfloor air distribution systems: A literature overviews. In Proceedings of the 23rd Conference on Passive and Low Energy Architecture, Geneva, Switzerland, 6-8 September 2006.

18. Alajmi, A.F.; Abou-Ziyan, H.Z.; El-Amer, W. Energy analysis of under-floor air distribution (UFAD) system: An office building case study. Energy Convers. Manag. 2013, 73, 78-85. [CrossRef]

19. Kong, Q.; Yu, B. Numerical study on temperature stratification in a room with underfloor air distribution system. Energy Build. 2008, 40, 495-502. [CrossRef]

20. Lee, K.; Xue, G.; Jiang, Z.; Chen, Q. Thermal environment in indoor spaces with under-floor air distribution systems: 1 . Impact of design parameters (1522-RP). HVAC R Res. 2012, 18, 1182-1191.

21. Lin, Y.J.P.; Linden, P.F. A model for an underfloor air distribution system. Energy Build. 2005, 37, 399-409. [CrossRef]

22. Tsai, T.-Y.; Liou, R.-H.; Lin, Y.-J.P. An Experimental Study on the Indoor Environment Using UnderFloor Air Distribution System. Procedia Eng. 2014, 79, 263-266. [CrossRef]

23. Schiavon, S.; Lee, K.H.; Bauman, F.; Webster, T. Influence of raised floor on zone design cooling load in commercial buildings. Energy Build. 2010, 42, 1182-1191. [CrossRef]

24. Bauman, F.S.; Jin, H.; Webster, T. Heat transfer pathway in underfloor air distribution (UFAD) systems. ASHRAE Trans. 2006, 112, 2.

25. Schiavon, S.; Lee, K.H.; Bauman, F.; Webster, T. Simplified calculation method for design cooling loads in underfloor air distribution (UFAD) systems. Energy Build. 2011, 43, 517-528. [CrossRef]

26. Lee, K.H.; Schiavon, S.; Bauman, F.; Webster, T. Thermal decay in underfloor air distribution (UFAD) systems: Fundamentals and influence on system performance. Appl. Energy 2012, 91, 197-207. [CrossRef]

27. Yu, B.H.; Seo, B.; Hong, S.H.; Yeon, S.H.; Lee, K.H. Influences of different operational configurations on combined effects of room air stratification and thermal decay in UFAD system. Energy Build. 2018, 176, 262-274. [CrossRef]

28. Liu, Q.; Ryu, Y.; Kagawa, H.; Kojima, T. Influence of crawlspace design and utilization on thermal environment in detached house with insulated foundation for moderate and humid climate region. J. Environ. Eng. (Trans. AIJ) 2006, 71, 31-38. [CrossRef]

29. Rantala, J. A new method to estimate the periodic temperature distribution underneath a slab-on-ground structure. Build. Environ. 2005, 40, 832-840. [CrossRef]

30. Krarti, M. Steady-State heat transfer from horizontally insulated slabs. Int. J. Heat Mass Transf. 1993, 36, 2135-2145. [CrossRef]

31. Krarti, M. Time-Varying heat transfer from horizontally insulated slab-on-grade floors. Build. Environ. 1994, 29, 63-71. [CrossRef]

32. Krarti, M. Steady-State heat transfer from slab-on-grade floors with vertical insulation. Int. J. Heat Mass Transf. 1993, 36, $2147-2155$. [CrossRef]

33. Krarti, M. Time-Varying heat transfer from slab-on-grade floors with vertical insulation. Build. Environ. 1994, 29, 55-61. [CrossRef]

34. Hagentoft, C.-E. Steady-State heat loss for an edge-insulated slab: Part I. Build. Environ. 2002, 37, 19-25. [CrossRef]

35. Iwamae, A.; Nagai, H.; Suzuki, H.; Kitatani, Y. A quantitative analysis on heat loss around the basement of insulated house. J. Environ. Eng. (Trans. AIJ) 2003, 68, 37-42. [CrossRef]

36. Seduikyte, L.; Stasiulienè, L.; Prasauskas, T.; Martuzevičius, D.; Černeckienė, J.; Ždankus, T.; Dobravalskis, M.; Fokaides, P. Field Measurements and Numerical Simulation for the Definition of the Thermal Stratification and Ventilation Performance in a Mechanically Ventilated Sports Hall. Energies 2019, 12, 2243. [CrossRef] 
37. Iguchi, M.; Hachisu, H.; Sakamoto, Y. Verification of air distribution, thermal environment and energy consumption in an existing detached house-A methodology for designing the air-conditioning system using floor-chambers in a residence Part 4 . J. Environ. Eng. AIJ 2016, 81, 1137-1145. [CrossRef]

38. Iguchi, M.; Hachisu, H.; Sakamoto, Y. Comparison between thermal simulations and measurements of an existing detached house-A methodology for designing the air-conditioning system using floor-chambers in a residence Part 5. J. Environ. Eng. AIJ 2019, 84, 947-954. [CrossRef]

39. Kishi, T.; Lee, S.; Asano, Y. Thermal environment by adjusting air flow rate for blown fan of central air-conditioning system for residential building. J. Environ. Eng. AIJ 2020, 85, 37-44. [CrossRef]

40. ISO 10551. Ergonomics of the Thermal Environment-Assessment of the Influence of the Thermal Environment Using Subjective Judgement Scales; International Organization for Standardization: Geneva, Switzerland, 1995.

41. Standard for Measurement of Psychological and Physiological Responses to Thermal environments, Architectural Institute of Japan Environmental Standards; Architectural Institute of Japan: Tokyo, Japan, 2014.

42. ASHRAE Fundamental 2013 CAPTER9 Thermal Comfort. American Society of Heating; Refrigerating and Air Conditioning Engineers, Inc.: Atlanta, GA, USA, 2013.

43. Benton, C.C.; Bauman, F.S.; Fountain, M.E. A field measurement system for the study of thermal comfort. ASHRAE Trans. 1990, 96,1 .

44. Tanaka, S.; Takeda, H.; Iwata, T.; Tsuchiya, T.; Terao, M.; Akimoto, T. Architectural Environmental Engineering, 4th ed.; Inoue Shoin Co., Ltd.: Tokyo, Japan, 2014. (In Japanese)

45. Nakaya, T. Basis of the Architectural Environmental Engineering-Heat Transfer of the Building Wall Affected by The Sun; Pubfull: Tokyo, Japan, 2018. (In Japanese)

46. Yamaguchi, T.; Katsura, T.; Nakamura, Y. Establishment of a measuring technique for calorie output from variable refrigerant flow air conditioning system by applying refrigerant enthalpy method and verification. J. Environ. Eng. (Trans. AIJ) 2015, 80, 1063-1071. [CrossRef]

47. Kocyigit, N.; Bulgurcu, H.; Lin, C.-X. Fault diagnosis of a vapor compression refrigeration system with hermetic reciprocating compressor based on p-h diagram. Int. J. Refrig. 2014, 45, 44-54. [CrossRef]

48. Oseland, N.A. A comparison of the predicted and reported thermal sensation vote in homes during winter and summe. Energy Build. 1994, 21, 45-54. [CrossRef]

49. Wang, Z. A field study of the thermal environment in residential buildings in Harbin. ASHRAE Trans. 2003, 109, 350-355.

50. Wang, Z. A field study of the thermal comfort in residential buildings in Harbin. Build. Environ. 2006, 41, 1034-1039. [CrossRef]

51. Tobita, K.; Nakaya, T.; Matsubara, N.; Kurazumi, Y.; Shimada, R. Calculation of neutral temperature and acceptable range by the field study of houses in Kansai area, Japan, in winter. J. Environ. Eng. (Trans. AIJ) 2007, 72, 71-77. [CrossRef]

52. Rijal, H.B.; Yoshida, H.; Umemiya, N. Seasonal and regional differences in neutral temperatures houses. Build. Environ. 2010, 45, 2743-2753. [CrossRef]

53. Wang, Z.; Zhang, L.; Zhao, J.; He, Y. Thermal comfort for naturally ventilated residential buildings in Harbin. Energy Build. 2010, 42, 2406-2415. [CrossRef]

54. Wang, Z.; Zhang, L.; Zhao, J.; He, Y.; Li, A. Thermal responses to different residential environments in Harbin. Build. Environ. 2011, 46, 2170-2178. [CrossRef]

55. Liu, H.; Wu, Y.; Li, B.; Cheng, Y.; Yao, R. Seasonal variation of thermal sensations in residential buildings in the Hot Summer and Cold Winter zone of China. Energy Build. 2017, 140, 9-18. [CrossRef]

56. Jiao, Y.; Yu, H.; Wang, T.; An, Y.; Yu, Y. Thermal comfort and adaptation of the elderly in free-running environments in Shanghai, China. Build. Environ. 2017, 118, 259-272. [CrossRef]

57. Wang, Z.; Yu, H.; Jiao, Y.; Wei, Q.; Chu, X. A field study of thermal sensation and neutrality in free-running aged-care homes in Shanghai. Energy Build. 2018, 158, 1523-1532. [CrossRef]

58. Gautam, B.; Rijal, H.B.; Shukuya, M.; Imagawa, H. A field investigation on the wintry thermal comfort and clothing adjustment of residents in traditional Nepalese houses. J. Build. Eng. 2019, 26, 100886. [CrossRef]

59. Xiong, Y.; Liu, J.; Kim, J. Understanding differences in thermal comfort between urban and rural residents in hot summer and cold winter climate. Build. Environ. 2019, 165, 106393. [CrossRef]

60. Jiao, Y.; Yu, H.; Yu, Y.; Wang, Z.; Wei, Q. Adaptive thermal comfort models for homes for older people in Shanghai, China. Energy Build. 2020, 215, 109918. [CrossRef]

61. Jin, Y.; Carpenter, M.; Weller, R.B.; Tabor, D.; Payne, S.R. The effect of indoor thermal and humidity condition on the oldest-old people's comfort and skin condition in winter. Build. Environ. 2020, 174, 106790. [CrossRef]

62. Shao, T.; Jin, H. A field investigation on the winter thermal comfort of residents in rural houses at different latitudes of northeast severe cold regions, China. J. Build. Eng. 2020, 32, 101476. [CrossRef] 